Research Article

\title{
Tartaric Acid-Modified Holarrhena antidysenterica and Citrullus colocynthis Biowaste for Efficient Eradication of Crystal Violet Dye from Water
}

\author{
Sumaira Basharat, ${ }^{1}$ Rabia Rehman ${ }^{D},{ }^{1}$ Tariq Mahmud, ${ }^{1}$ Sara Basharat, ${ }^{2}$ and Liviu Mitu $\mathbb{D D}^{3}$ \\ ${ }^{1}$ Institute of Chemistry, University of the Punjab, Lahore 54590, Pakistan \\ ${ }^{2}$ Department of Chemistry, University of Education, Lahore, Pakistan \\ ${ }^{3}$ Department of Nature Sciences, University of Pitesti, Pitesti 110040, Romania
}

Correspondence should be addressed to Rabia Rehman; grinorganic@yahoo.com and Liviu Mitu; ktm7ro@yahoo.com

Received 23 September 2020; Revised 26 November 2020; Accepted 4 December 2020; Published 16 December 2020

Academic Editor: Hassan Arida

Copyright (c) 2020 Sumaira Basharat et al. This is an open access article distributed under the Creative Commons Attribution License, which permits unrestricted use, distribution, and reproduction in any medium, provided the original work is properly cited.

\begin{abstract}
Two novel adsorbents Holarrhena antidysenterica (HA) and Citrullus colocynthis (CC) were collected from native Pakistan and treated with tartaric acid. The adsorbents were characterized by Fourier-transform infrared spectroscopy (FT-IR) and scanning electron microscopy, and their adsorptive behavior was studied against model cationic dye crystal violet (CV). Role of biosorbent dose, time of contact, temperature studies, agitation rates, and solution $\mathrm{pH}$ was investigated. Optimum conditions obtained for the removal of $\mathrm{CV}$ dye for $\mathrm{H}$. antidysenterica-tartaric acid modified (HA-TA) were as follows: $0.8 \mathrm{~g}$ adsorbent dose, 35 minutes contact time, $5.0 \mathrm{pH}, 40^{\circ} \mathrm{C}$ temperature, and $150 \mathrm{rpm}$ agitation rates as compared to $H$. antidysenterica that gave $1.4 \mathrm{~g}$ adsorbent dose, 40 minutes time of contact, $6.0 \mathrm{pH}, 50^{\circ} \mathrm{C}$ temperature, and $150 \mathrm{rpm}$ agitation speed. C. colocynthis-tartaric acid modified (CC-TA) removed $\mathrm{CV}$ dye at $0.6 \mathrm{~g}$ adsorbent dose, 30 minutes contact interval, $4.0 \mathrm{pH}, 40^{\circ} \mathrm{C}$ temperature, and $125 \mathrm{rpm}$ agitation speed in contrast to C. colocynthis which gave $0.8 \mathrm{~g}$ adsorbent dose, 40 minutes time of contact, $6.0 \mathrm{pH}, 50^{\circ} \mathrm{C}$ temperature, and $125 \mathrm{rpm}$ agitation speed, respectively. Isothermal studies for both raw and modified biosorbents were compliant with the Langmuir model indicating monolayer, chemisorption. The maximum Langmuir capacities were up to $128.20 \mathrm{mg} / \mathrm{g}, 136.98 \mathrm{mg} / \mathrm{g}$, $144.92 \mathrm{mg} / \mathrm{g}$, and $166.66 \mathrm{mg} / \mathrm{g}$ for HA, CC, HA-TA, and CC-TA. Pseudo-second-order kinetic model well fitted the dye removal data. The rate-determining steps involved both surface and intraparticle diffusion mechanisms. Adsorption of dye molecules on active surfaces was governed by electrostatic attractions and chelating abilities. Thermodynamics research revealed the spontaneous and exothermic nature of the reaction. The adsorbents serve promising candidates for the effective removal of hazardous dyes from aqueous solutions.
\end{abstract}

\section{Introduction}

Environment around us is constantly being damaged, due to the incessant release of waste substances, even at minute amounts. Multiple industries such as textile, paints, and plastics contain dyes in their wastewaters. Dyes are chemical compounds that have aromatic rings and high degree of saturation which adhere to any fiber or material and impart characteristic color to it [1-4]. When discharged into water, they are difficult to degrade and biological entities suffer severe damage due to their structure, such as high mitotic index and chromosomal and nuclear aberrations [5-9]. Thus, the treatment of wastewaters has been major concerns for centuries. Traditional approaches such as coagulation, sedimentation, ion-exchange, flocculation, reverse osmosis, electrochemical operation, and biological treatments [10] have the delimitations of high energy consumption, expensive equipment, incomplete ion removal, and toxic sludge production [11], and none of them provide complete color removal from wastewater, so constant efforts are made in continuation of the newest approach [12]. Adsorption therefore is a far superior method to all these methods 
because of its cheapness and high efficiency. Biowastes comprise many functional groups that encapsulate a wide variety of organic and inorganic pollutants. Moreover, higher capacities, adsorption rates, kinetics, and pollutant selectivity along with nominal pretreatment make them outstanding candidates replacing activated carbon, which is most frequently used and is quite expensive [13].

Crystal violet (CV) having molecular formula $\mathrm{C}_{25} \mathrm{H}_{30} \mathrm{~N}_{3} \mathrm{Cl}$ is also known as basic violet 3 , gentian violet, and methyl violet $10 \mathrm{~B}$. Its IUPAC name is $N$-[4-[bis[4dimethylamino-phenyl]-methylene]-2,5-cyclohexadien-1ylidine]- $N$-methylmethanaminium chloride. It belongs to triaryl methane dyes having $\lambda_{\max }$ from 589 to $594 \mathrm{~nm}$, and molecular weight is 407.98 . It is utilized as a bacteriostatic agent [14] and is an active ingredient in Gram's stain and is used for disinfection [15]. It is a purple dye used in ink and paints and cotton and silk textile industries [16]. Its harmful effects include pain provoking sensitivity to sunlight, eye irritation, persistent trauma to the eye, and damage to cells of mammals [17]. In extreme cases, absorption through skin results in skin and digestive tract irritation causing permanent blindness, respiratory, and kidney failure [18]. It has been removed from wastewaters using membrane separation techniques, electrocoagulation, ozonization, photocatalysis, and adsorption [19-22] among which the most promising is adsorption [13]. Various adsorbents such as $\mathrm{NaOH}$-modified rice husk, bottom ash, coir pith, sawdust, sugarcane fiber, zeolites, stalks, clays, stems, wheat straws, and pyrophyllites have been utilized for CV dye removal [6, 23-34].

The adsorbents used in this study are novel Holarrhena antidysenterica and Citrullus colocynthis. $H$. antidysenterica is commonly addressed as Inderajao and Kurai and belongs to Apocynaceae family. It is favored in many medical areas such as for the treatment of dysentery and skin inflammations and helps in the cure of osteoporosis and rheumatism [35]. It contains a variety of functional groups due to the presence of steroidal alkaloids, flavonoids, triterpenoids, phenolic acids, tannin, resin, coumarins, saponins, and ergosterol [36] along with cellulose, hemicellulose, and lignin. These groups provide oxygen, nitrogen, phenol, and organic carboxylic acid moieties that provide ambient groups for the scavenging of CV from wastewaters.

C. colocynthis is called as Indrayan and Colocynth and belongs to Cucurbitaceae family. It is similar to peanuts, an ordinary plantation residing in temperate wilderness, helps in treatment for breast cancer and diabetes, and stimulates increase in hair length [37]. Many chemical groups such as carbohydrates, proteins, amino acids, tannins, saponins, phenolics, flavonoids, flavone glucosides, terpenoids, alkaloids, anthranol, steroids, cucurbitacins, saponarin, cardiac glycosides, and trace elements are present in it [38].

Both the adsorbents are cheap ( $5 \$$ per $\mathrm{kg}$ ), easily available in Asian countries and highly effective, providing great removal capacities both in raw and modified forms. Acidic treatment reduces the chances in fungal or bacterial growth, improving the efficiency of the biowaste for scavenging dyes from wastewaters on industrial level.

This work aims to (a) explore novel, cheap adsorbents $\mathrm{HA}$ and $\mathrm{CC}$, from indigenous agricultural resources in
Pakistan, modify with tartaric acid to enhance their sorption capacity, increasing shelf life (b) to characterize the raw and treated adsorbents by different techniques such as FTIR and SEM (c) test for removing CV dye from wastewaters by various adsorption parameters such as dose, agitation speed, time of contact, $\mathrm{pH}$, and temperature studies, along with statistical modelling of isothermal, kinetics, and thermodynamics (d) new theoretical results contributing towards a deeper understanding of the mechanism involved for the adsorption of crystal violet dye on the adsorbents, further enhancing the worth of this work.

\section{Materials and Methods}

2.1. Preparation of the Biosorbents. Biosorbents HA and CC were acquired from the regional marketplace of Lahore, Pakistan. They were washed first with tap water and then by distilled water. Left over moisture was removed by sun drying. The final adsorbent was grinded into 60 mesh size by using an electric grinder. For chemical modification, the obtained powder was soaked in $10 \%$ tartaric acid aqueous solution and then filtered and dried again prior to usage.

2.2. Chemicals. Analytical grade chemicals were utilized. Crystal violet dye, Basic Violet 3, C.I. 42555, molecular weight: $407.98 \mathrm{~g} \cdot \mathrm{mol}^{-1}$, and $\lambda_{\text {max }}: 590 \mathrm{~nm}$ was obtained from Sigma-Aldrich (Merck, Germany). $\mathrm{HCl} 37 \%$ of $11.6 \mathrm{M}$, having molecular weight: $36.46 \mathrm{~g} \cdot \mathrm{mol}^{-1}$ was obtained from Sigma-Aldrich (Merck, Germany). $\mathrm{NaOH}$ having molecular weight: $40 \mathrm{~g} \cdot \mathrm{mol}^{-1}$ from Sigma-Aldrich (Merck, Germany) was used. UV/Vis spectrophotometer (Labomed UVD-3500, China) was used for the absorbance calibrations at $\lambda_{\max }$ : $590 \mathrm{~nm}$. For controlling $\mathrm{pH}, \mathrm{pH}$ meter (Hanna, USA) was used. Orbital shaker (model OSM-747), Fourier-Transform Infrared (FT-IR) spectrometer (Agilent Cary 630, USA), and scanning electron microscope (Nova Nano Scanning Electron Microscope (SEM) 450 and Thermo Fischer Scientific, USA) were also utilized for this research work.

\subsection{Selection of Chemical Treatment Applied for Medication of} Biosorbents. Chemical modification enhances biosorption capacity and increases stability of biosorbents by reducing moisture contents, retarding biological decomposition due to fungal or bacterial attack [39]. Functionality of biosorbent is also enhanced due to uniform distribution of ions. Especially acid modifications yield increased protonation $[40,41]$ and ester linkages [42] while basic treatment provided high micropore percentages [43]. Rapid achievement of equilibrium is attained [44]. To check the best performance, $0.1 \mathrm{M}$ hydrochloric acid, $0.1 \mathrm{M}$ sodium hydroxide, methanol, ethanol, iso-propanol, iso-butanol, acetone, urea [45], thio-urea [46], citric acid [47, 48], tartaric acid [49], and ethylene diamine tetra acetic acid (EDTA) [50] were used. Tartaric acid gave the maximum biosorption capacity, so it was selected for further studies, as shown in Figure $1.5 \mathrm{~g}$ of HA and CC was selected and added in aqueous solutions of $25 \mathrm{~mL}$ of abovementioned solvents and kept in glass beakers 


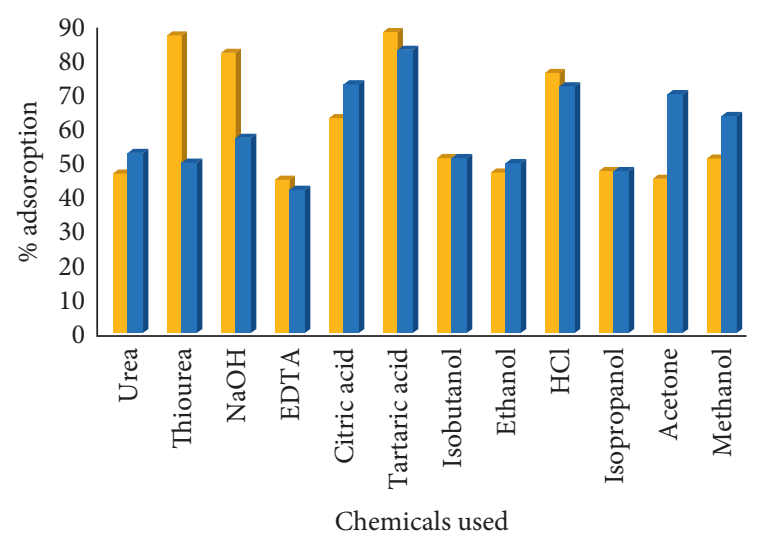

- $\mathrm{HA}-\mathrm{CV}$

- $\mathrm{CC}-\mathrm{CV}$

Figure 1: Chemical modification of adsorbents.

for 4 hours approximately. The containers were completely covered by aluminum sheets. These solutions were subjected to filtration. After drying, $0.5 \mathrm{~g}$ of the resultant biosorbent residue was added to $25 \mathrm{ml}$ of $10 \mathrm{mg} / \mathrm{L} \mathrm{CV}$ dye solution, for 15 minutes at $100 \mathrm{rpm}$. Filtration of the resultant solutions helped in determining the final dye concentrations [51].

2.4. Batch Adsorption Studies. Dye standard solutions $(5-25 \mathrm{mg} / \mathrm{L})$ were prepared from stock solutions $(1000 \mathrm{mg} /$ L). Batch wise experiments comprised the study of time effects, adsorbent dose, $\mathrm{pH}$ studies, temperatures, and agitation rates. Dye concentration was monitored in filtrates using a UV/Vis spectrophotometer at $\lambda_{\text {max }}: 590 \mathrm{~nm}$.

For contact time studies, 5 minutes to one hour with a difference of 5 minutes each was selected. $0.4 \mathrm{~g}$ of adsorbents was added to $25 \mathrm{mg} / \mathrm{L}$ dye solution, revolving at $100 \mathrm{rpm}$ at ambient temperatures.

Adsorbent dose was studied by selecting a range of $0.2 \mathrm{~g}$ to $2 \mathrm{~g}$ of adsorbents, added to $25 \mathrm{mg} / \mathrm{L}$ dye solutions, and agitated at $100 \mathrm{rpm}$ at room temperature for 35 minutes.

For $\mathrm{pH}$ effects, range of $1-10$ was selected. $0.4 \mathrm{~g}$ of adsorbents was added to $25 \mathrm{mg} / \mathrm{L}$ dye solution and agitated at $100 \mathrm{rpm}$ at room temperature for half hour.

Temperature studies were done at $20-80^{\circ} \mathrm{C}$ range with $10^{\circ} \mathrm{C}$ interval. $0.4 \mathrm{~g}$ of adsorbents was added to $25 \mathrm{mg} / \mathrm{L}$ dye solution and rotated at $100 \mathrm{rpm}$ at room temperature for half hour.

$25 \mathrm{rpm}$ to $200 \mathrm{rpm}$ range with $25 \mathrm{rpm}$ interval was selected for agitation speeds study. $0.4 \mathrm{~g}$ of adsorbents was added to $25 \mathrm{mg} / \mathrm{L}$ dye solution and rotated for different speeds at ambient temperatures for 30 minutes.

For isothermal studies, $10-40 \mathrm{mg} / \mathrm{L}$ concentrations of $\mathrm{CV}$ dye along with optimum parameter conditions were used. For kinetic studies, $25 \mathrm{mg} / \mathrm{L}$ dye solutions was selected at $25^{\circ} \mathrm{C}$ with all optimized conditions. Thermodynamic studies were employed utilizing raw and modified forms with a temperature range of $283-323 \mathrm{~K}$.

The experiments were repeated, and percentage adsorption of dye was studied as follows:

$$
\text { adsorption }(\%)=C_{o}-\frac{C_{e}}{C_{o}} \times 100,
$$

where $C_{o}(\mathrm{mg} / \mathrm{L})$ is the initial CV dye concentration and $C_{e}$ $(\mathrm{mg} / \mathrm{L})$ is the adsorption at equilibrium. The amount of dye adsorbed per unit mass is given as follows:

$$
q=\left(C_{o}-C_{e}\right) \frac{V}{m},
$$

where $q(\mathrm{mg} / \mathrm{g})$ is the quantity of dye adsorbed by the adsorbent, $V(\mathrm{~L})$ is volume of dye solution, and $m(\mathrm{~g})$ is the mass of biowaste used $[52,53]$.

\section{Results and Discussion}

3.1. FTIR Analysis before and after Adsorption. FTIR spectra for the CV dye adsorption on untreated HA (Figure 2(a)) were obtained, and it ensures the dominance of hydroxyl groups along with carboxylic moieties, on the sites of adsorbent. The peaks at $3904.4 \mathrm{~cm}^{-1}$ to $3482.5 \mathrm{~cm}^{-1}$ are responsible for the presence of $-\mathrm{OH}$ (bending), physically adsorbed water molecules [54]. Also, $3011.9 \mathrm{~cm}^{-1}$ represents carboxylic acid moieties. Bands at $2921.8 \mathrm{~cm}^{-1}$ and $2852.1 \mathrm{~cm}^{-1}$ represent asymmetric and symmetric C-H groups, and $2366.2 \mathrm{~cm}^{-1}$ shows $\mathrm{CO}_{2}$ from the atmosphere. $1740.4 \mathrm{~cm}^{-1}$ shows aldehyde stretch. $1636.3 \mathrm{~cm}^{-1}$ peaks depict doubly bonded carbons of alkene moieties, whereas $1457.6 \mathrm{~cm}^{-1}$ shows aromaticity. Also, $1168.3 \mathrm{~cm}^{-1}$ represents $\mathrm{C}-\mathrm{N}$ groups. When $\mathrm{CV}$ dye on the acid-treated $\mathrm{HA}$ was seen (Figure 2(b)), bands from $3919.5 \mathrm{~cm}^{-1}$ till $3502.5 \mathrm{~cm}^{-1}$ represent the free hydroxyl moieties. Decreased bands were observed at $2922.5 \mathrm{~cm}^{-1}$ and $2852.3 \mathrm{~cm}^{-1}$ for C-H functional groups, indicating the reaction has been occurred. $2359.9 \mathrm{~cm}^{-1}$ shows single bonded alkanes. Alkyne functional groups were depicted by stretching at $1989 \mathrm{~cm}^{-1}$, while $1789 \mathrm{~cm}^{-1}$ represents alkenes. $1559.2 \mathrm{~cm}^{-1}$ shows aromaticity, while $1718.5 \mathrm{~cm}^{-1}$ represents aldehydic groups. $1363.5 \mathrm{~cm}^{-1}$ represents bending of alkanes.

$\mathrm{CC}$ when reacts with $\mathrm{CV}$ (Figure 2(c)) displays wide peaks from $3841 \mathrm{~cm}^{-1}$ to $3328 \mathrm{~cm}^{-1}$ that are responsible for the presence of hydroxyl groups indicating the reaction of the dye with the adsorbent. Stretching at $2183 \mathrm{~cm}^{-1}$ represents double bonds of alkynes. $1636 \mathrm{~cm}^{-1}$ indicates the presence of doubly bonded carbons of alkenes, and peaks at $1419 \mathrm{~cm}^{-1}$ represent $C=C$ of aromatic rings, indicting the presence of $\mathrm{CV}$ dye within the adsorbent surfaces. $1705 \mathrm{~cm}^{-1}$ displays $-C=O$ stretch of aldehydes, while $1363 \mathrm{~cm}^{-1}$ shows the presence of $-\mathrm{N}=\mathrm{O}$ groups. Band at $1029 \mathrm{~cm}^{-1}$ contributes to $\mathrm{C}-\mathrm{N}$ groups of aliphatic amines. Acid-modified CC adsorbent when reacts with CV dye (Figure 2(d)) displays reduced consecutive peaks from $3902 \mathrm{~cm}^{-1}$ to $3447 \mathrm{~cm}^{-1}$, showing the presence of freed $\mathrm{OH}$ groups which is due to the reaction between dye and adsorbent [19]. Peak at $2132 \mathrm{~cm}^{-1}$ contributes towards unsaturated $-\mathrm{C}=\mathrm{C}$ bonds of alkyne moieties. $1653 \mathrm{~cm}^{-1}$ stretching responds towards the doubly bonded carbon groups, and $1314.1 \mathrm{~cm}^{-1}$ contributes towards the nitrile stretching $\mathrm{CN}$ of aromatic amines. $1363 \mathrm{~cm}^{-1}$ stretch depicts $-\mathrm{N}=\mathrm{O}$ groups, and $1028 \mathrm{~cm}^{-1}$ confirms the presence of $-\mathrm{CN}$ stretch of aliphatic amines. After dye adsorption, bands 


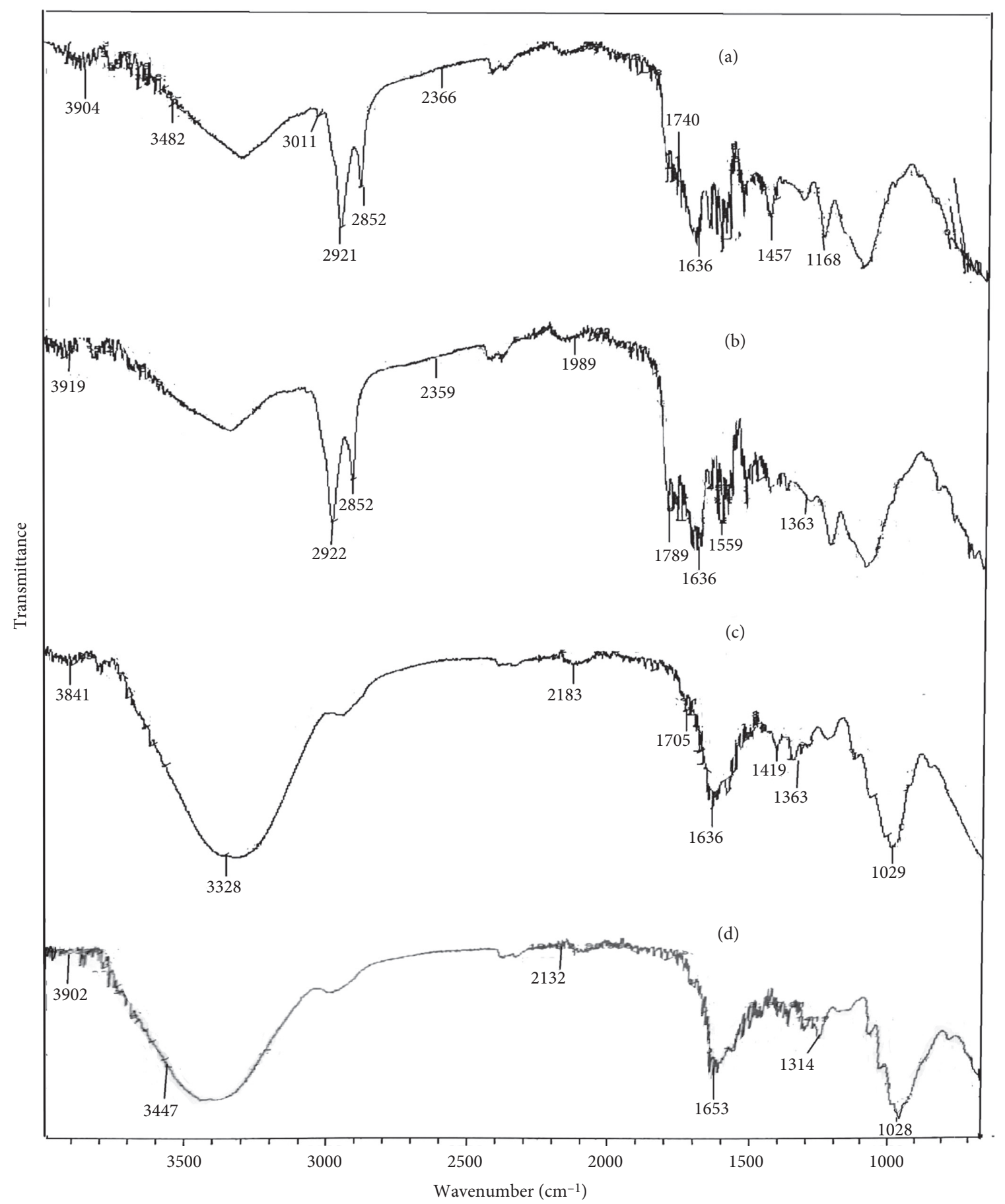

FIgURe 2: Infrared spectrum showing the main adsorption bands: (a) HA + CV; (b) HA-TA + CV; (c) CC + CV; (d) CC-TA + CV.

intensity decreases and elongated bands of $-\mathrm{OH}$ widens, confirming the reaction of CV dye with the adsorbents. The presence of oxygen containing functional moieties provides more adsorption surfaces and thus helps in the achievement of greater adsorption of dyes. The nitrogen groups facilitate the eradication of dyes and organic pollutants.

3.2. SEM Analysis. HA (Figure 3(a)) displayed voids [19] in between compact, agglomerated, spherical structures [10].
Tartaric acid modification resulted in conversion of round structures to flaky, crumpled, chiseled ones containing numerous voids/cages/channels that provide additional surface sites for CV adsorption (Figure 3(b)). CC displayed large flaky structures with channels between them (Figure 3(c)). Acidic modification resulted in numerous spherical, vertical, agglomerated compact structures, offering many potential sites for dye adsorption (Figure 3(d)). The presence of granular structures of acid moieties, clustered well on surface, is evident of the successful preparation of the adsorbent. 


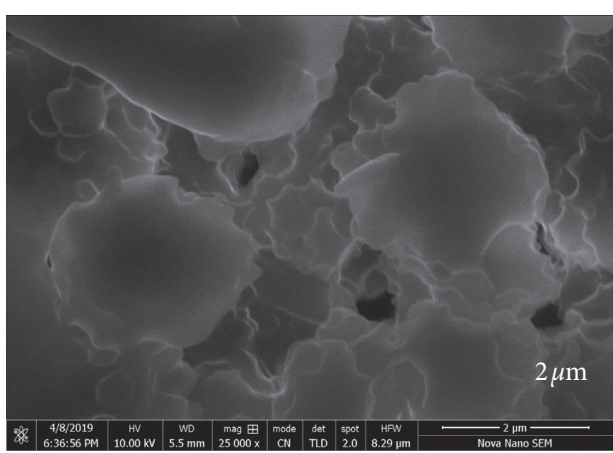

(a)

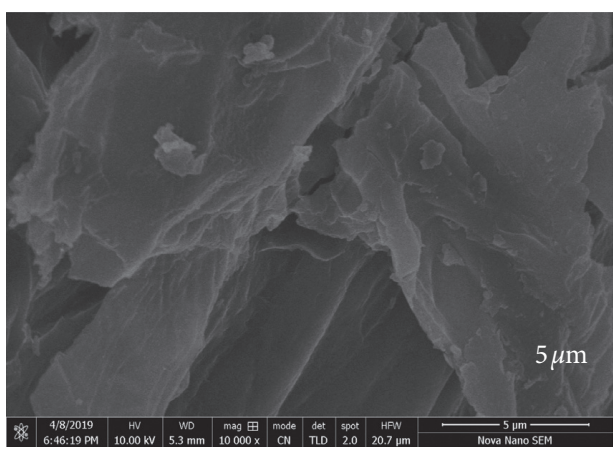

(c)

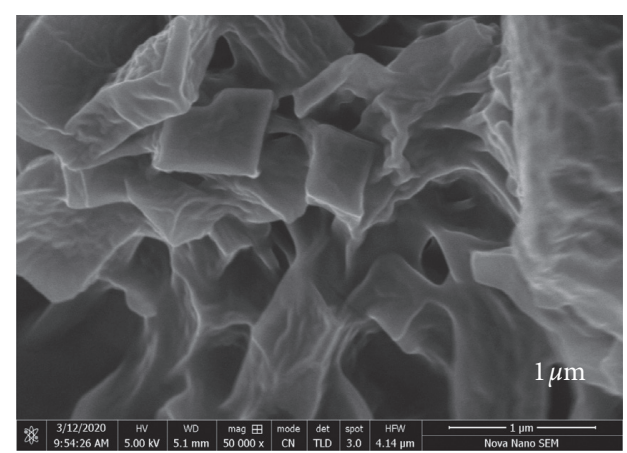

(b)

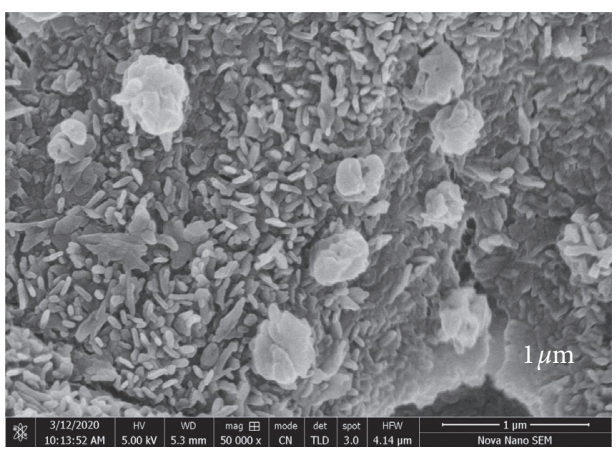

(d)

Figure 3: SEM of (a) HA, (b) HA-TA, (c) CC, and (d) CC-TA.

3.3. Factors Affecting Adsorption of Dyes on the Biosorbents. Different factors such as adsorption dosage, $\mathrm{pH}$ effect, time of contact, temperature, and agitation rates were employed for the determination of equilibrium parameters for the eradication of $\mathrm{CV}$ on to the raw and modified adsorbents.

3.3.1. Impact of Biosorbent Dose. Biosorbent dose is a significant criterion towards the achievement of biosorption efficiency. At low concentration, maximum adsorption is achieved due to availability of many adsorption sites, but at higher concentration, less saturation of surfaces leads towards a lower dye removal. $0.2-2 \mathrm{~g}$ dose of adsorbents was selected. For HA, 96\% dye removal was observed at $1.4 \mathrm{~g}$ after which the dye establishes equilibrium with the adsorbent. The modified HA develops equilibrium at $0.8 \mathrm{~g}$ removing $97 \%$ of the dye. Figure 4 (a) displays the \% age removal of the $\mathrm{CV}$ dye with the raw and tartaric acidmodified adsorbents. Acid treatment incorporates the addition of oxygen containing functional moieties that chelate the dye molecules increasing the rates of adsorption. CC adsorbent removed CV dye up to $97 \%$ at $0.8 \mathrm{~g}$, whereas the acid treated yielded $97.5 \%$ dye removal at $0.6 \mathrm{~g}$. Decrease in adsorption after equilibrium is due to decline in amount biosorbed by unit mass of the sorbent, leaving vacant adsorption sites [55].

3.3.2. Impact of Time of Contact. Time of contact helps in rate determining steps and possible mechanism involved. Adsorption raised up to a certain time until equilibrium is achieved [56]. The decrease in adsorption is due to the repulsion among the adsorbed ions towards the unadsorbed ones. The experiment was allowed to run for a 60-minute time period with a difference of 5 minutes (Figure 4(b)). HA removed $97 \% \mathrm{CV}$ dye at 40 minutes as compared to tartaric acid-modified form which gave $97 \%$ dye removal at 35 minutes. A steady decrease in rate of adsorption was observed after reaching plateau (saturation point) due to complete saturated adsorption surfaces. CC observed $86 \%$ dye removal at 40 minutes which raised to $98 \%$ at $30 \mathrm{~min}$ for the modified form. Modification helped in availability of more active sites which increased the biosorption efficiencies. This increase may be attributed to (a) dye molecules crossing the outer boundary layer and (b) diffusion of $\mathrm{CV}$ towards the internal exfoliated porous surface (intraparticle diffusion) along with reduction in viscosities and lower complexation [57-59]; however, accumulation of dye fragments over the period of time halts the adsorption at the later stages [37].

3.3.3. Impact of $p H$. The effect of $\mathrm{pH}$ on solution holds prime importance as the molecules are self-ionizable. Point of zero charge pHpzc is the isoelectronic point where the negative and positive surfaces become equivalent $[60,61]$. Negative charged surface is formed if the $\mathrm{pH}$ is higher than pHpzc due to deprotonation of functional moieties like $\mathrm{OH}$ and COO-groups; thus, cationic dyes adsorption occurs; however, if the $\mathrm{pH}$ is less than $\mathrm{pHpzc}$, surface becomes positively charged because of protonation [10]. Hence, anionic dyes adsorption occurs. Initial $\mathrm{pH}$ is taken at the $x$ - 


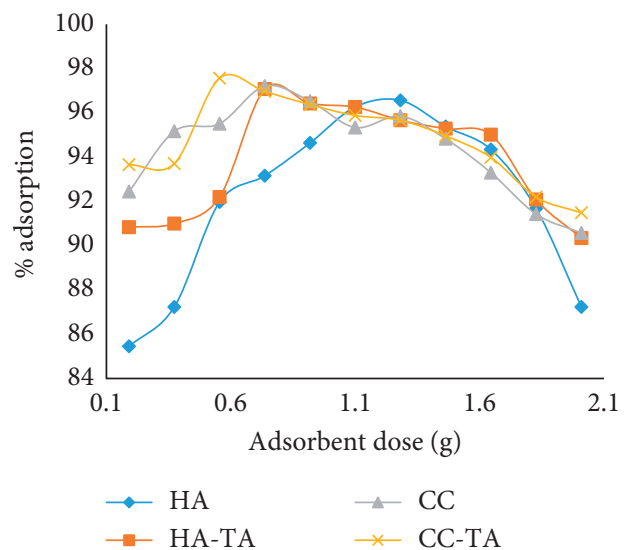

(a)

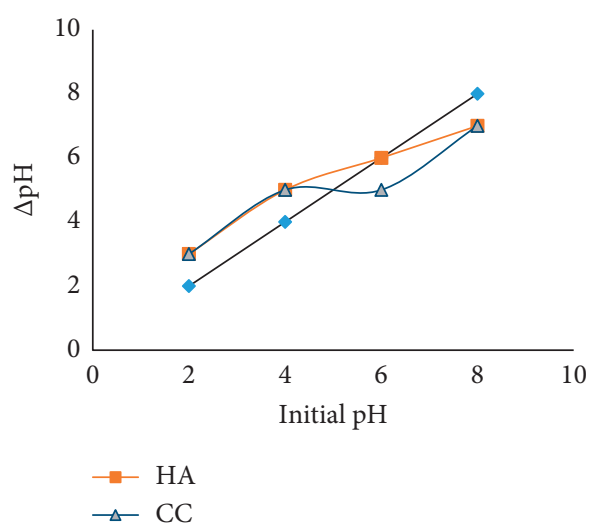

(c)

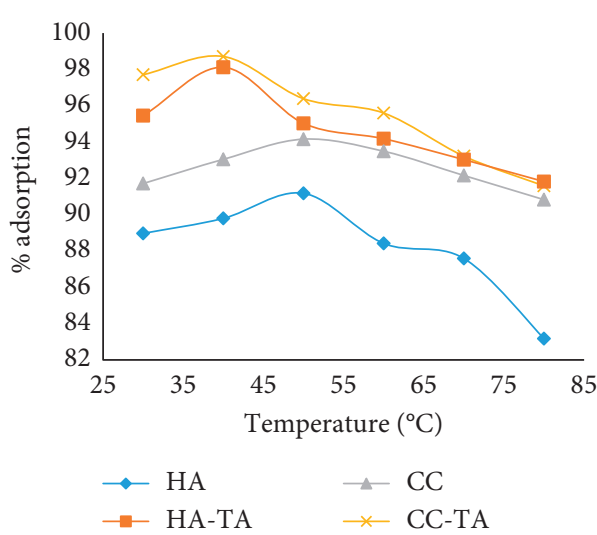

(e)

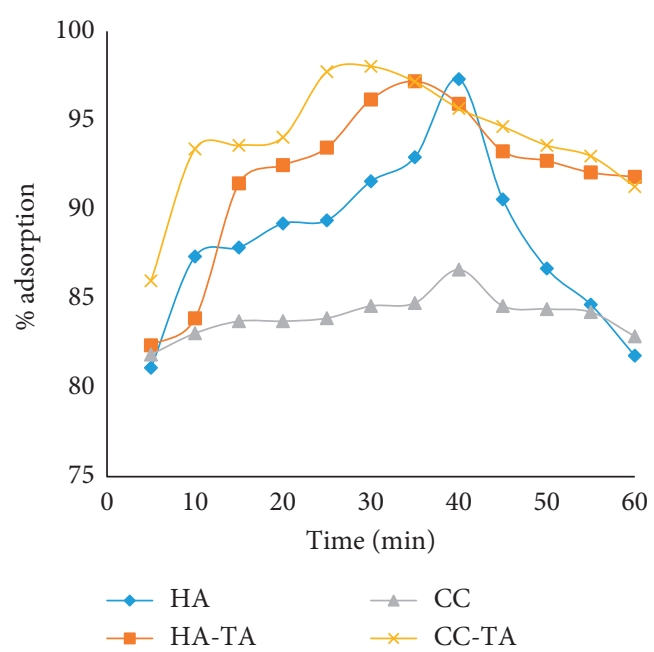

(b)

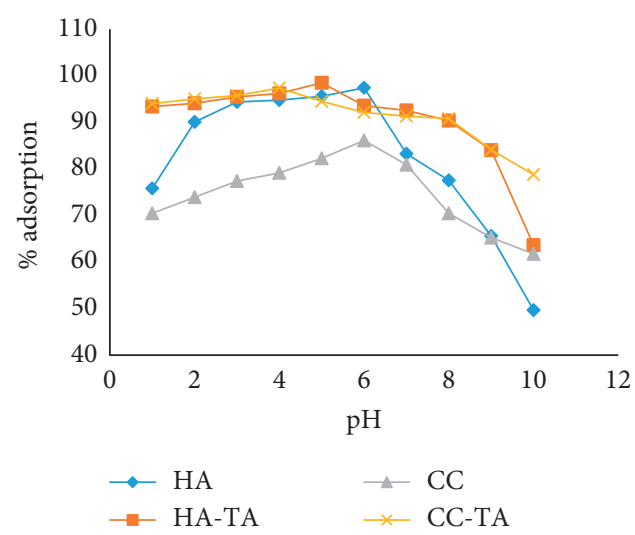

(d)

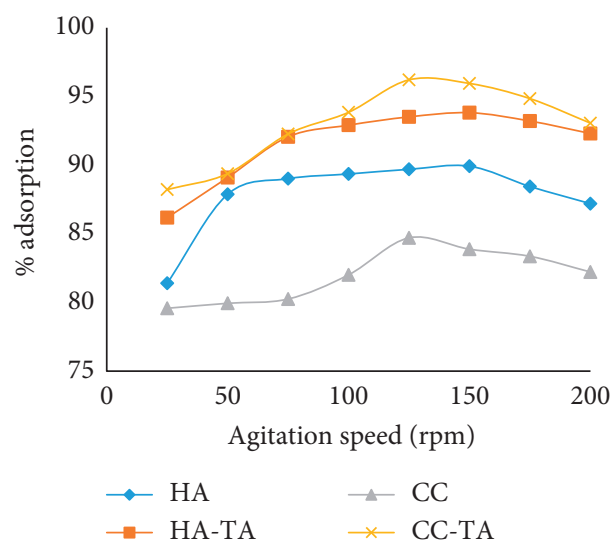

(f)

Figure 4: Adsorptive parameters for CV adsorption: (a) adsorbent dose; (b) time of contact; (c) pHpzc of HA and CC; (d) pH effects; (e) temperature studies; (f) rates of agitation.

axis, and difference between initial and final $(\Delta \mathrm{pH})$ is taken as the $y$-axis to find the value of pHpzc, as shown in Figure 4(c). It was determined by an electrochemical method [62], where $50 \mathrm{~mL}$ of $(0.05 \mathrm{M})$ sodium chloride was added to a series of beakers, $\mathrm{pH}$ was adjusted from 2 to 10 by adding appropriate amounts of hydrochloric acid (0.1 M) and sodium hydroxide $(0.1 \mathrm{M})$, followed by addition of $40 \mathrm{mg}$ adsorbent. The prepared solutions were kept at constant agitation at room temperature for 48 hours [60]. The $\mathrm{pHpzc}$ for HA is 6, whereas CC is 5 that infers to a negative surface above this $\mathrm{pH}$ and below a positive one.

As seen in Figure 4(d), adsorption capacity was found $97 \%$ at $\mathrm{pH} 6$ for $\mathrm{HA}$, whereas $\mathrm{CC}$ showed $86 \%$ dye removal at $\mathrm{pH}$ 6. This is because the interactions between the charged 
dye ions and adsorbent surfaces control the adsorption capacities. $\mathrm{CV}^{+}$is a cationic dye. As the number of -OH ions increases, solution $\mathrm{pH}$ and adsorption capacities of the dye tend to increase. Low eradication of dye in the acidic circumstances was assigned towards the struggle for potential sites, among the cationic part of the dye and the $\mathrm{H}^{+}$ions, therefore contributing an immense feature in the electrostatic mechanism of adsorption method $[60,63]$. When surface ionized density is low, it provides repulsion in the dye particles and adsorbent sites, thus offering adsorption in acidic environment [64]. Here, $\mathrm{CV}$ and excess $\mathrm{H}^{+}$ions compete for adsorption sites, thus lowering adsorption capacity in the basic medium; also, adsorbent surface hydrolysis creates positive charged sites, thus rendering the favorable adsorption of the dye in an acidic medium. Tartaric acid-modified HA gave $98 \%$ dye adsorption at $\mathrm{pH} 5$ as compared to modified CC which gave $97 \%$ at $\mathrm{pH} 4$.

3.3.4. Impact of Temperature. Temperature impacts on the biosorption procedure imply whether it is an exothermic or endothermic one [27]. The study was done for the adsorptive removal of $\mathrm{CV}$ dye on raw and tartaric acid-treated adsorbents and observed the adsorption decreases along with the increase in temperature, indicating the process might be an exothermic one. This increase is attributed to the increase in movement of the CV dye particles with the rise in kinetic energy and enhanced rates of intraparticle diffusion. Furthermore, increasing temperature brings swelling effect which increases further penetration of the dye molecules. A range of $30^{\circ} \mathrm{C}-80^{\circ} \mathrm{C}$ was selected for the temperature studies, as seen in Figure $4(\mathrm{e}) ; 91 \%$ adsorption at $50^{\circ} \mathrm{C}$ was observed for $\mathrm{HA}$ which increased to $98 \%$ at $40^{\circ} \mathrm{C}$ for treated HA, while CC displayed $94 \%$ dye removal at $50^{\circ} \mathrm{C}$ that raised to $98.7 \%$ at $40^{\circ} \mathrm{C}$ for modified CC.

3.3.5. Impact of Agitation Speed. The distribution of solutes among the bulk and external boundary films formation is determined by rotating speed. CV reduces the resistance of the external boundary sheet resulting in favored correlation of dyes to that of the biosorbent, thus rising movement. Better adsorption of the dye molecules resulted in the increased external mass transfer coefficient [65]. Agitation speed with a range of 20-200 rpm was checked for CV dye removal on raw and tartaric acid-modified forms, and $89 \%$ adsorption efficiency was observed at $150 \mathrm{rpm}$ for HA that elevated to $93 \%$ for modified HA, whereas CC gave $84 \%$ dye removal at $125 \mathrm{rpm}$ that increased to $96 \%$ for modified CC, as shown in Figure 4(f).

3.4. Isothermal Studies. A relationship between adsorbate and sorbent was established to fully comprehend the environment of adsorption process and reaction mechanism by utilizing isothermal models. These are Langmuir, Freundlich, Temkin, and the D-R isotherms.

The relationships among the equilibrium bulk concentrations and masses of adsorbate per unit weight of adsorbent is given by the Langmuir model. Also, it says that adsorption takes place homogeneously on the adsorption sites $[66,67]$. The linear model of the Langmuir isotherm is given as follows:

$$
\frac{1}{q_{e}}=\frac{1}{b q_{\max }} \cdot \frac{1}{C_{e}}+\frac{1}{q_{\max }} \text { (Langmuir), }
$$

where $C_{e}$ is the liquid phased concentrations of the $\mathrm{CV}$ dye at the equilibrium stage $\left(\mathrm{mg} \cdot \mathrm{L}^{-1}\right), q_{\max }$ is the monolayer sorption capacity of the adsorbents $\left(\mathrm{mg} \mathrm{g}^{-1}\right), q_{e}$ is the concentration of dye adsorbed on the biosorbent at equilibrium $\left(\mathrm{mg} \cdot \mathrm{g}^{-1}\right)$, and $b$ represents energy of biosorption $\left(\mathrm{L} \cdot \mathrm{g}^{-1}\right)$. A plot of $1 / C_{e}$ vs. $1 / q_{e}$ gives a straight line for this isotherm (Figure 5(a)). The dimensionless equilibrium parameter $R_{L}$ which is also used for evaluating the possibility of the biosorption process is obtained by employing the underlying equation:

$$
R_{L}=\frac{1}{1+K_{L} \cdot C_{o}},
$$

where $C_{o}$ is the highest initially dye concentrations $\left(\mathrm{mg}^{-\mathrm{g}^{-1}}\right)$ and $K_{\mathrm{L}}$ is the Langmuir adsorption constant $\left(\mathrm{L} \cdot \mathrm{mg}^{-1}\right)$. Adsorption is favorable if $0<R_{L}<1$, unfavorable if $R_{L}>1$, linear if $R_{L}=1$, or irreversible if $R_{L}=0$ [66].

As seen in Table 1, Langmuir removal capacities $q_{\max }$ for biosorption of $\mathrm{CV}$ dye on the raw and modified biosorbents displayed higher values for the modified form as compared to the raw ones, indicating that the acid-treated biosorbents display better adsorption capacity for $\mathrm{CV}$ dye due to the availability of more binding sites of their masses and also increase in functional groups, as depicted by the FTIR spectrum which favors the adsorption of dye. $Q_{\max }$ was found to be highest for CC-TA among the four adsorbents. $R^{2}$ values were highest in Langmuir as compared to Freundlich, Temkin, and D-R isotherms indicating homogeneous, chemisorption with no side reactions [66]. Positive $b$ values are clearly indicative of the appreciable affinities of the biosorbents towards the removal of $\mathrm{CV}$ dye. $R_{L}$ values were less than 1, displaying a favorable adsorption procedure.

Heterogeneous surfaces in multilayer adsorption along with nonuniform distribution of heat of surface adsorption are presumed by Freundlich [68]. Its linear form is represented as follows:

$$
\log q_{e}=\log K_{f}+\frac{1}{n} \log C_{e} \text { (Freundlich), }
$$

where $K_{F}$ is the Freundlich constant which relates towards biosorption capacity and $n$ is the biosorption strength factor, in which 1-10 value is indicative of favorable biosorption, $n>2, n<1$, and $n=0-1$ are representative of better, average, and good adsorptions [69], and $1 / n$ is the constant related to intensity of biosorption or heterogeneity factor. $1 / n<1$ displays Freundlich isotherm, whereas $1 / n>1$ indicates cooperative biosorption [66]. Graphical plots of log qe vs. log Ce give a straight line from which values of $n$ and $K_{\mathrm{F}}$ are determined from the slope and intercept of the graphical plot (Figure 5(b)). When checked for Freundlich Isotherm as in Table 1, it was dawned upon that $R^{2}$ values were lesser 


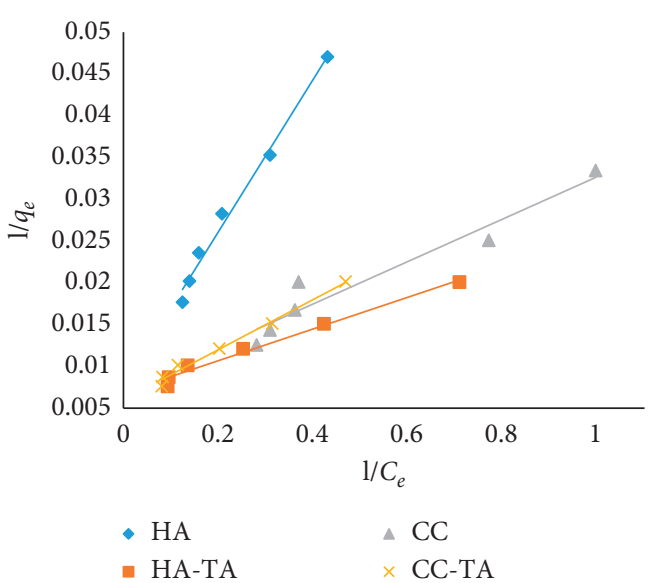

(a)

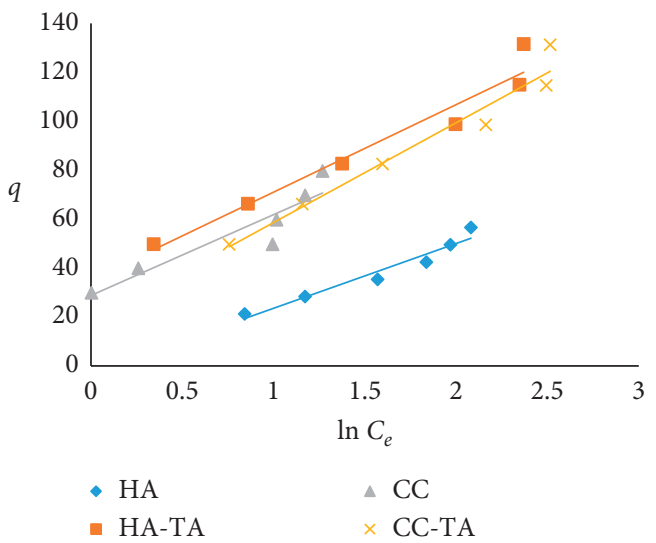

(c)

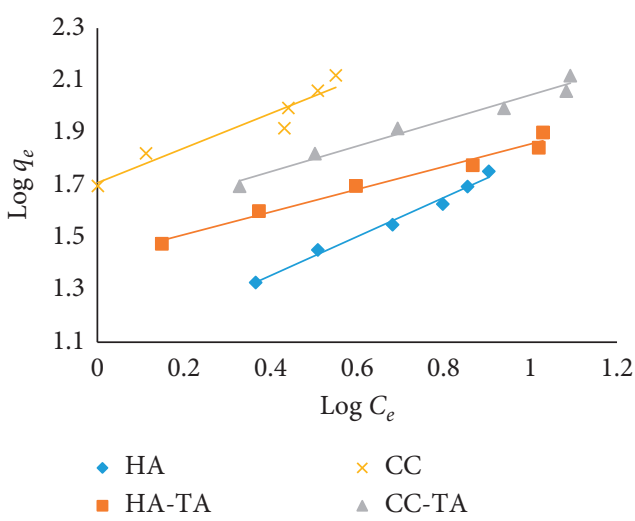

(b)

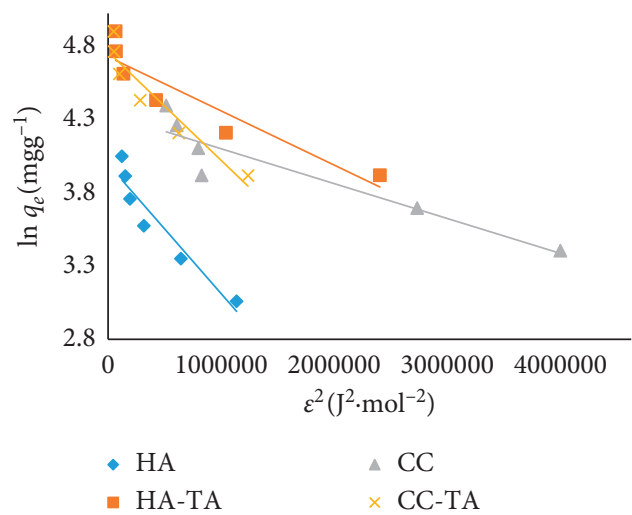

(d)

Figure 5: Comparative representation of (a) Langmuir, (b) Freundlich, (c) Temkin, and (d) D-R isotherms.

TABLE 1: Isothermal parameters for CV dye removal.

\begin{tabular}{|c|c|c|c|c|}
\hline Isotherm model & $\mathrm{HA}$ & HA (acid treated) & $\mathrm{CC}$ & CC (acid treated) \\
\hline \multicolumn{5}{|l|}{ Langmuir } \\
\hline$Q_{m}(\mathrm{mg} / \mathrm{g})$ & 128.2051 & 144.9275 & 136.9863 & 166.6667 \\
\hline$R_{L}(\mathrm{~L} / \mathrm{mg})$ & $0.28-0.12$ & $0.08-0.03$ & $0.10-0.04$ & $0.14-0.05$ \\
\hline$b(\mathrm{~L} / \mathrm{g})$ & 0.085620 & 0.363158 & 0.287401 & 0.200669 \\
\hline$R^{2}$ & 0.9887 & 0.9891 & 0.9344 & 0.9881 \\
\hline RMSE & 5.009201 & 260.7283 & 24.08263 & 35.54608 \\
\hline \multicolumn{5}{|l|}{ Freundlich } \\
\hline$n$ & 1.341921 & 2.331546 & 1.497230 & 2.047083 \\
\hline $1 / n$ & 0.7452 & 0.4289 & 0.6679 & 0.4885 \\
\hline$K_{\mathrm{f}}(\mathrm{mg} / \mathrm{g})$ & 11.38413 & 44.30982 & 30.73265 & 35.99979 \\
\hline$R^{2}$ & 0.9873 & 0.9781 & 0.9181 & 0.9742 \\
\hline RMSE & 15.403682 & 266.34286 & 28.824900 & 56.289299 \\
\hline \multicolumn{5}{|l|}{ Temkin } \\
\hline$B(\mathrm{~J} / \mathrm{mol})$ & 0.070466 & 0.098277 & 0.078881 & 0.154763 \\
\hline$A(\mathrm{~L} / \mathrm{g})$ & 1.02453319 & 1.1155827 & 2.3966132 & 7.8249 \\
\hline$R^{2}$ & 0.9488 & 0.9524 & 0.8607 & 0.9568 \\
\hline \multicolumn{5}{|l|}{$\mathrm{D}-\mathrm{R}$} \\
\hline$Q_{m}(\mathrm{mg} / \mathrm{g})$ & 53.6349 & 110.819 & 75.3542 & 114.377 \\
\hline$B_{D}\left(\mathrm{~mol}^{2} / \mathrm{KJ}^{2}\right)$ & $9 \times 10^{-7}$ & $4 \times 10^{-7}$ & $2 \times 10^{-7}$ & $8 \times 10^{-7}$ \\
\hline$E_{D}(\mathrm{KJ} / \mathrm{mol})$ & 1.991 & 2.353 & 2.161 & 2.369 \\
\hline$R^{2}$ & 0.9057 & 0.8631 & 0.8703 & 0.8998 \\
\hline RMSE & 19.94108 & 6871.246 & 68.49695 & 111.5207 \\
\hline
\end{tabular}


than Langmuir's; moreover, values of $n$ were found between 1 and 2, favoring good adsorption characteristics. The relatively higher charge to mass ratio of the $\mathrm{CV}$ dye particles along with favorable chelating capabilities of modified forms was accountable for the favorable dye eradication.

Temkin isotherms only validate for an intermediate range of ionic concentrations and consider indirect adsorbate/adsorbate interactions. Moreover, it also conveys that an increase in surface coverage decreases heats of biosorption ( $\Delta H$ ads) of all the particles in the films [70]. Linear form of this isotherm is given as

$$
q_{e}=B \ln C_{e}+B \ln A(\text { Temkin }),
$$

where $A_{T}=$ equilibrium binding constant related to maximum binding energy $\left(\mathrm{L} \cdot \mathrm{g}^{-1}\right)$ and $B_{T}=$ Temkin isotherm constant relating to adsorption heat $\left(\mathrm{J} \cdot \mathrm{mol}^{-1}\right)$ [71]. Physical or chemical interactions among the dyes and adsorbent are given by $B_{T}$ values, where $<8$ shows physical nature while $>8$ is representative of chemical interactions [72, 73]. Less than 8 values of $B_{T}$, as shown in Table 1 , depicts the weak and physical forces between the dye molecule and the adsorbents. Graph between $q$ and $\ln C_{e}$ gives the desired results (Figure 5(c)). Tartaric acid offered strong binding forces for the dye molecules exhibiting an increase in the $B_{T}$ for the modified forms in comparison to raw biosorbents. Unsatisfactory fitting of the Temkin model is observed due to less $R^{2}$ values than the Langmuir and Freundlich ones.

Dubinin-Radushkevich isothermic model [74] represents biosorption mechanism with Gaussian energy distributions onto heterogeneous surfaces. It is only appropriate for intermediate ranges of biosorbate concentration. The model describes pore filling mechanism and consists of semiempirical equation that qualitatively describes the biosorption of gases and vapours on microporous sorbents [75]. It assumes a multilayer character for physical adsorption involving Van der Waal's forces. Linearly, it is shown as following equations:

$$
\begin{gathered}
\ln q_{e}=\ln q_{m}-B_{D} \varepsilon^{2}(\text { Dubinin }- \text { Radushkevich }), \\
\varepsilon=R T \ln \left(1+\frac{1}{C_{e}}\right)
\end{gathered}
$$

$q_{e}$ is the $\mathrm{CV}$ adsorbed on adsorbents, $C_{e}$ is the concentration of $\mathrm{CV}$ at equilibrium, $q_{m}\left(\mathrm{mg} \cdot \mathrm{g}^{-1}\right)$ is the Dubinin-Radushkevich constant related to degree of adsorption. $B_{\mathrm{D}}\left(\mathrm{mol}^{2} \cdot \mathrm{kJ}^{-2}\right)$ is the free energies of $\mathrm{CV}$ dye that travel from infinite distance towards the sorbent, and $\varepsilon$ is the Polanyi potential. Mean free energy, $E(\mathrm{~kJ} / \mathrm{mol})$, is calculated as follows:

$$
E=\frac{1}{\sqrt{2 B}}
$$

Value of $E$ also inferences about adsorption mechanism where $E<8 \mathrm{~kJ} \cdot \mathrm{mol}^{-1}$ represents physisorption, while $8<E<16 \mathrm{~kJ} \cdot \mathrm{mol}^{-1}$ shows ion-exchange and $E>16 \mathrm{~kJ} \cdot \mathrm{mol}^{-1}$ displays chemisorption process [76].
In Table $1, R^{2}$ values were found to be less than those of Langmuir isotherm, and values of $q_{m}$ were found to be increasing for the modified forms which might be because of the increase in possible spots as a result of acid treatment. $E$ values gave results lesser than 8 inferring the biosorption procedure to be physiosorption. Figure $5(\mathrm{~d})$ displays the comparative adsorption for D-R isotherm.

3.5. Kinetic Study. The rate and mechanism of the reaction can be studied from kinetic modelling to ensure a competent and swift biosorption procedure for commercial purposes. For this purpose, popular kinetic models like Elovich, Lagergren pseudo-first-order kinetics, and Lagergren pseudo-second-order kinetics are employed. Quantitative checking can also be done by using percent relative deviation $(P)$, as follows:

$$
P(\%)=\frac{100}{N} \sum\left\{\frac{q_{e(\exp )}-q_{e(\mathrm{cal})}}{q_{e(\exp )}}\right\},
$$

where $q_{e(\exp )}$ is the experimented biosorption capability (mg/ $\mathrm{g}), q_{e(\mathrm{cal})}$ is the biosorption capacities obtained after calculations by utilizing kinetic models $(\mathrm{mg} / \mathrm{g})$, and $N$ is the total number of observations [77].

The Elovich model is based on the principal that adsorption increases exponentially with adsorption sites implying multilayered adsorption [78]. Chemisorption of gas onto solids was first described by this equation [79]. Linear form of the Elovich equation is shown as follows [80]:

$$
q t=\frac{\ln (a \times b)}{b}+\frac{\ln t}{b}(\text { Elovich })
$$

where $q t(\mathrm{mg} / \mathrm{g})$ is the concentration of dye adsorbed at any time $t, \alpha(\mathrm{g} / \mathrm{mg} \mathrm{min})$ is the initial rate of sorption, and $b(\mathrm{~g} /$ $\mathrm{mg}$ ) is linked to number of potential sites covering the surfaces. Higher $\alpha$ values represent chemisorption. For this model, maximum adsorption capacity along with Elovich constants can be calculated from slope and intercept of graph of $\ln t$ versus $q t$. Table 2 represents the Elovich parameters obtained for raw and modified adsorbents, and Figure 6(a) displays graphs obtained after adsorption.

Lagergren pseudo-first-order kinetic model was established upon the assumption that adsorption is equivalent to the amount of freely bonded surfaces [81, 82].

It is shown as follows:

$$
\ln \left(q_{e}-q_{t}\right)=\ln q_{e}-k_{1} t(\text { pseudo }- \text { first }- \text { order }),
$$

where $K_{1}\left(\mathrm{~h}^{-1}\right)$ is the rate constant and $q_{\mathrm{t}}\left(\mathrm{mg} \cdot \mathrm{g}^{-1}\right)$ represents the quantity of $\mathrm{CV}$ dye taken at any instant $t$ while $q_{e}(\mathrm{mg}$ $\mathrm{g}^{-1}$ ) shows the quantity of $\mathrm{CV}$ dye taken at the equilibrium stage. A larger variance $(P)$ amidst the experimented and calculated $q_{e}$ values renders the first-order ineffective. Negative $P$ values show that $q_{\mathrm{e}}$ calculated was higher than $q_{e}$ experimental. Moreover, lesser values of correlation coefficient $R^{2}$ implement the unsatisfactory fittings of the pseudo-first-order model, as evident in Table 2 and Figure 6(b). 
TABLe 2: Kinetic parameters for CV dye removal.

\begin{tabular}{|c|c|c|c|c|}
\hline Kinetic model & HA & HA (acid treated) & $\mathrm{CC}$ & CC (acid treated) \\
\hline \multicolumn{5}{|l|}{ Elovich } \\
\hline$a(\mathrm{~g} / \mathrm{mg} \mathrm{min})$ & 2.126335 & 4.231261 & 2.187151 & 4.968411 \\
\hline$b(\mathrm{~g} / \mathrm{mg})$ & 16.12903 & 6.169031 & 3.648304 & 3.031222 \\
\hline$R^{2}$ & 0.4506 & 0.7526 & 0.8017 & 0.8255 \\
\hline RMSE & 7938.098 & 4817.005 & 159202.223 & 774074.334 \\
\hline \multicolumn{5}{|l|}{ Pseudo-first-order } \\
\hline$q_{\mathrm{e}}(\exp )(\mathrm{mg} / \mathrm{g})$ & 1.071428571 & 2.2 & 2 & 2.833333 \\
\hline$q_{\mathrm{e}}(\mathrm{cal})(\mathrm{mg} / \mathrm{g})$ & 0.058695 & 7.316443 & 2.5211576 & 1.4537844 \\
\hline$k_{1}\left(\min ^{-1}\right)$ & 0.058496 & 0.0508963 & 0.0265 & 0.2047367 \\
\hline$R^{2}$ & 0.5643 & 0.5485 & 0.5599 & 0.9437 \\
\hline$P(\%)$ & 10.16647 & -11.25655 & 7.3942122 & 3.20232563 \\
\hline RMSE & 240 & 71 & 571 & 1789 \\
\hline \multicolumn{5}{|l|}{ Pseudo-second-order } \\
\hline$q^{-1}$ & 0.344 & 1.010 & 0.484 & 0.548 \\
\hline$k_{2}(\mathrm{~g} /(\mathrm{mg} \min ))$ & 1.741 & 0.622 & 0.353 & 0.229 \\
\hline$q_{\mathrm{e}(\mathrm{Cal})}(\mathrm{mg} / \mathrm{g})$ & 0.989 & 2.063 & 1.823 & 2.904 \\
\hline$t^{1 / 2}$ & 0.581 & 0.778 & 1.551 & 1.503 \\
\hline$h(\mathrm{mg} / \mathrm{g} \cdot \mathrm{min})$ & 1.706 & 2.652 & 1.176 & 1.932 \\
\hline$R^{2}$ & 0.9913 & 0.9981 & 0.992 & 0.9982 \\
\hline$P(\%)$ & 0.763 & 0.618 & 0.881 & -0.251 \\
\hline RMSE & 30 & 60 & 527 & 740 \\
\hline \multicolumn{5}{|l|}{ Intraparticle diffusion } \\
\hline$k_{i d}\left(\mathrm{mg} /\left(\mathrm{g} \cdot \min ^{1 / 2}\right)\right.$ & 0.035 & 0.0659 & 0.1087 & 0.1346 \\
\hline $\mathrm{C}\left(\mathrm{mg} \cdot \mathrm{g}^{-1}\right)$ & 0.7285 & 1.6135 & 1.0853 & 1.9484 \\
\hline$R^{2}$ & 0.6021 & 0.6401 & 0.6492 & 0.7075 \\
\hline \multicolumn{5}{|l|}{ Film diffusion } \\
\hline $\mathrm{K}_{\mathrm{FD}}(1 / \mathrm{min})$ & 0.0125 & 0.0145 & 0.0399 & 0.0889 \\
\hline$R^{2}$ & 0.8032 & 0.8478 & 0.9398 & 0.9437 \\
\hline
\end{tabular}

Ho's model $[83,84]$ is supported by the presumption that rate of reaction is equivalent to dye concentration, and the square of binding locations present on the biosorbent is shown as in the following equation:

$$
\left.\frac{t}{q}=\frac{1}{k_{2} q_{e}^{2}}+\frac{t}{q_{e}} \text { (pseudo }- \text { second }- \text { order }\right),
$$

where $k_{2}\left(\mathrm{~g} \mathrm{~g} \mathrm{~h}^{-1}\right)$ is the rate constant for pseudo-secondorder. Also, $q_{\mathrm{e}}(\mathrm{mg} / \mathrm{g})$ is the uptake capacity of CV dye at the equilibrium stage and $q_{t}(\mathrm{mg} / \mathrm{g})$ is the uptake capacity of CV dye at a given instant $t$.

The high value of $R^{2}$ and lower relative percentage deviation $(P \%)$ as compared to first-order kinetics indicates higher fitness of the pseudo-second-order model to the kinetics data. Moreover, $q_{e(\mathrm{cal})}$ is closest to that of $q_{e(\exp ) \text {, }}$ suggesting adsorption process to be chemisorption [85]. Initial rate of adsorption $(h)(\mathrm{mg} / \mathrm{g} \cdot \mathrm{min})$ is

$$
h=k_{2} q e^{2} .
$$

Product of uptake capacity and rate constant give the half-life $\left(t^{1 / 2}\right)$ of the adsorption process, and the time in which process is halved, as given in the following equation:

$$
t^{1 / 2}=\frac{1}{k_{2} q_{e}} .
$$

It was seen that $h$ values of the HA-TA and CC-TA displayed an increment in the initial sorption rate than unmodified ones, while half-life of modified adsorbents was lower than untreated ones $[43,86]$. Table 2 represents the desired results along with Figure 6(c).

For understanding of the mechanism of the biosorption process, intraparticle diffusion model was studied [82, 87], which is shown by Weber and Morris, as follows:

$$
q_{t}=k_{i d} t^{1 / 2} .
$$

The coefficient of intraparticle diffusion is represented by $k_{i d}$, and $C\left(\mathrm{mg} \mathrm{g}^{-1}\right)$ is the boundary layer effect. If the plot of $q_{t}$ vs. $t^{1 / 2}$ is a straight line and pass through the origin, then the intraparticle diffusion is the mechanism; otherwise, some other mechanisms are involved such as film diffusion [88]. Dual nature was observed for the plots for diffusion mechanism with the (a) first to be a curved line contributing towards boundary layer (surface diffusion) (b) and the straight line in the later stages inferring towards intraparticle diffusion (Figures 5(d) and 5(e)). This leads towards complex mechanism of the CV dye adsorption [19], as clear from Table 2. Not even one of the graphical plots passed through the origin; hence, it is concluded intraparticle diffusion model was not the complete mechanism involved [89].

Boyd proposed another mechanism for predicting the mechanism of the biosorption process which is based upon the fractional achievement of equilibrium with variance of time [90]. The following equation shows

$$
F=1-\frac{6}{3.1416^{2}} \exp \left(-B_{b} t\right)
$$




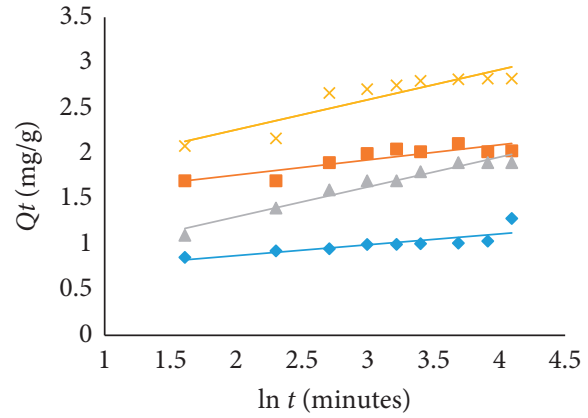

- HA

- HA-TA

(a)

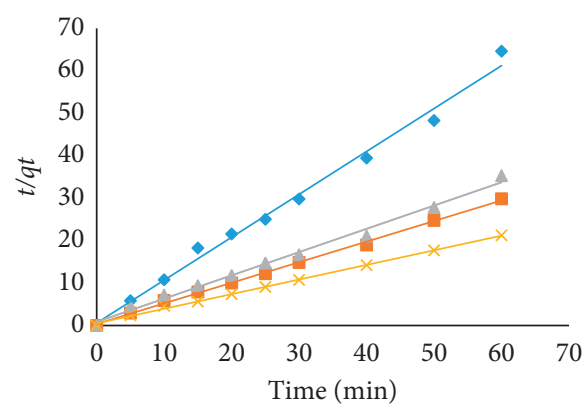

- HA

- HA-TA

$\triangle \mathrm{CC}$

$\times$ CC-TA

(c)

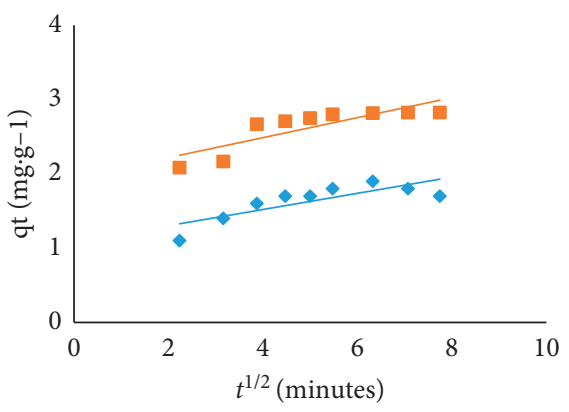

- CC

- CC-TA

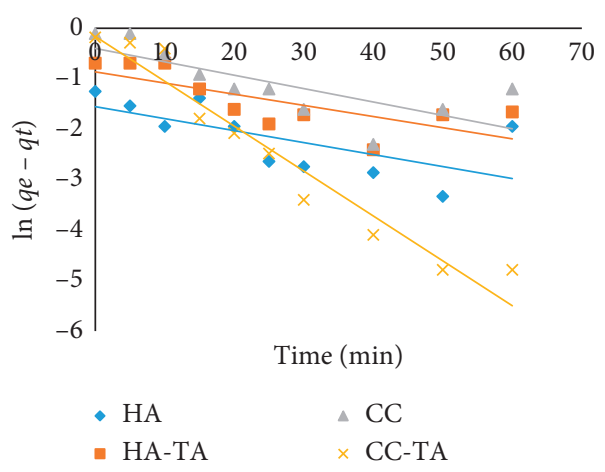

(b)

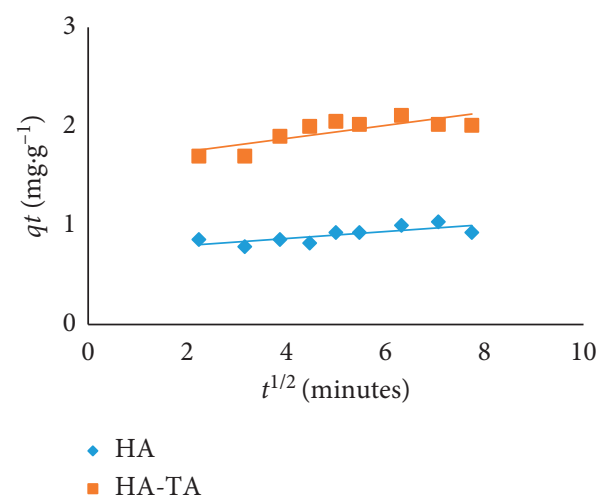

(d)

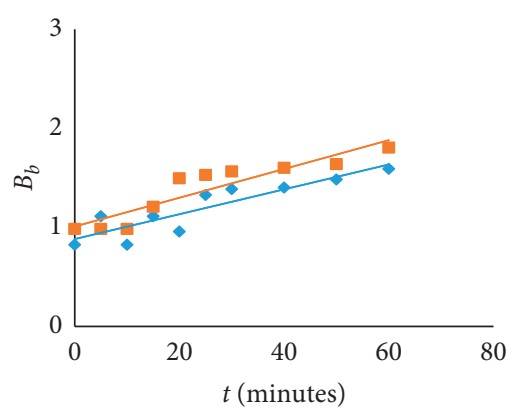

- HA

- HA-TA

(e)

(f)

Figure 6: Continued. 


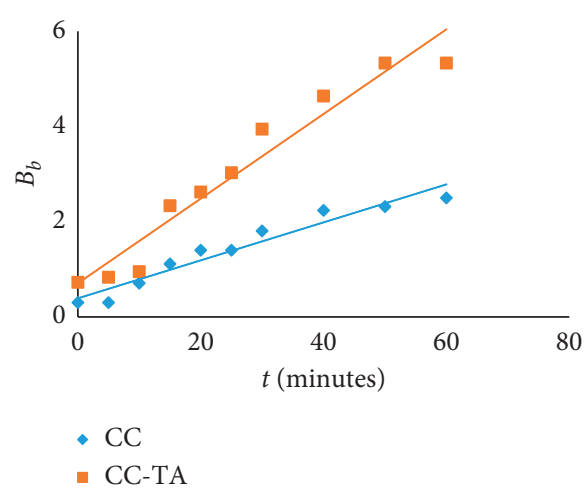

(g)

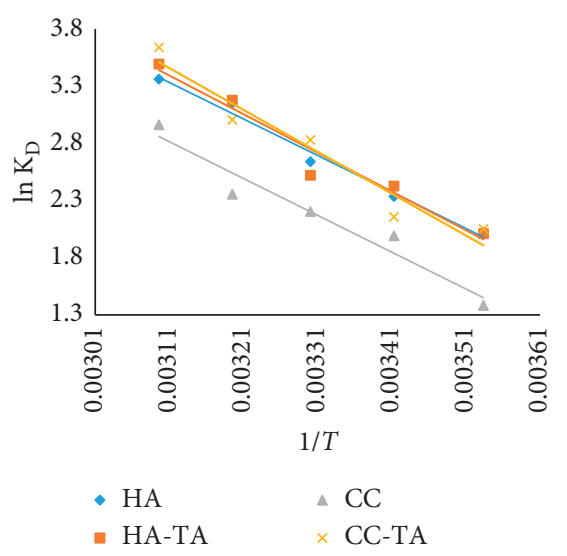

(h)

Figure 6: Kinetic plots: (a) Elovich plot; (b) pseudo-first-order; (c) pseudo-second-order; (d) intraparticle diffusion model for HA and HATA; (e) intraparticle diffusion model for CC and CC-TA; (f) film diffusion for HA and HA-TA; (g) film diffusion for CC and CC-TA for CV dye adsorption; (h) graphical representation of thermodynamic parameters of $\mathrm{CV}$ dye adsorption.

where Boyd's constant is represented by $B_{b}$ and the fractional achievement of equilibrium $q_{t} / q_{e}$ is shown by $F$ at any instant $t$. This equation is simplified as follows:

$$
B_{b}=-0.4977-\ln \left(1-\frac{q_{t}}{q_{e}}\right) .
$$

If a graph with a straight line passes through the origin, then the mechanism involved will be the Webber-Morris plot; otherwise, boundary layer diffusion will be the mechanism involved (Figures 5(f) and $5(\mathrm{~g})$ ). $R^{2}$ was compared in Table 2 and was seen that the graphs exhibited not only intraparticle diffusion behavior but also film or boundary layer as the rate determining step for the removal of CV dye on the raw and tartaric acid-modified biosorbents [10].

3.6. Nonlinear Fashion of Equilibrium and Kinetic Modelling. Nonlinear equations were employed to check the validation of the equilibrium data in the linear mode. Nonlinear equations of Langmuir, Freundlich, Temkin, and Dubnin-Radouskevich [91] are shown in the following equations:

$$
\begin{aligned}
& q_{e}=\frac{b \cdot q_{\max } \cdot c_{e}}{1+b \cdot c_{e}}, \\
& q_{e}=K_{f} C_{e}^{1 / n}, \\
& q_{e}=B_{T} \ln \left(K_{T} \cdot C_{e}\right), \\
& q_{e}=q_{m} \exp \left(-\beta \varepsilon^{2}\right) .
\end{aligned}
$$

Root mean square error (RMSE) values [92] were calculated using the following formula:

$$
\mathrm{RMSE}=\sqrt{\sum \frac{\left(q_{e(\mathrm{cal})}-q_{e(\mathrm{exp})}\right)^{2}}{N}} .
$$

Lesser value of RMSE as evident in Table 2 indicates the fitness of experimental to the calculated data.

From the alterations of linear equations, nonlinear equations of Elovich, pseudo-first-order, and pseudo-second-order forms [93] are obtained (equations (24)-(26)):

$$
\begin{aligned}
& q_{t}=\frac{1}{b}(\ln (a \cdot b \cdot t)), \\
& q_{t}=q_{e}\left(1-\exp -k_{1} t\right), \\
& q_{t}=\frac{t \cdot k_{2}\left(q_{e}\right)^{2}}{1+t k_{2} \cdot q_{e}}
\end{aligned}
$$

where $q_{t}(\mathrm{mg} / \mathrm{g})$ is the uptaking capacities of $\mathrm{CV}$ at any time $t, q_{e}(\mathrm{mg} / \mathrm{g})$ is the equilibrium binding capacities, $\alpha(\mathrm{g} / \mathrm{mg}$ $\mathrm{min})$ is the initial rate of adsorption, and $b(\mathrm{~g} / \mathrm{mg})$ is the number of active sites. $k_{1}\left(\mathrm{~h}^{-1}\right)$ and $k_{2}\left(g g^{-1}\right)$ are the firstand second-order rate constants, respectively.

RMSE results were calculated to investigate the most fitted of the kinetic models, comparing the experimental vs. calculated values, by using the following equation:

$$
\mathrm{RMSE}=\sqrt{\sum \frac{\left(q_{t(\mathrm{cal})}-q_{t(\exp )}\right)^{2}}{N}},
$$

where $q_{t(\mathrm{cal})}\left(\mathrm{mg} \cdot \mathrm{g}^{-1}\right)$ is the calculated binding capacity, $q_{t(\exp )}\left(\mathrm{mg}^{-1} \mathrm{~g}^{-1}\right)$ is the experimental binding capacity at any instant $t$, and $N$ is the number of observations. The lowest RMSE values are seen for those of second order hence making it most appropriate (Table 2).

3.7. Thermodynamic Studies. Temperature modifications affect the dye removal process as it instantly changes the kinetic energy involved in the procedure; increment in temperature results in raised diffusion in the lignocellulosic structures [94]. Vant Hoff's equation is given as follows: 
TABle 3: Thermodynamic parameters for CV dye adsorption.

\begin{tabular}{|c|c|c|c|c|c|}
\hline Adsorbents & $T(\mathrm{~K})$ & $\Delta G(\mathrm{KJ} / \mathrm{mol})$ & $K_{\mathrm{D}}$ & $\Delta H(\mathrm{KJ} / \mathrm{mol})$ & $\Delta S(\mathrm{~J} / \mathrm{mol} \mathrm{K})$ \\
\hline \multirow{5}{*}{ HA untreated } & 283 & -4.828 & 7.782 & \multirow{5}{*}{-63.5057} & \multirow{5}{*}{262.8423} \\
\hline & 293 & -5.788 & 10.758 & & \\
\hline & 303 & -6.783 & 14.767 & & \\
\hline & 313 & -8.396 & 25.179 & & \\
\hline & 323 & -8.961 & 31.267 & & \\
\hline \multirow{5}{*}{ Acid treated } & 283 & -4.79 & 67.676 & \multirow{5}{*}{-67.3621} & \multirow{5}{*}{276.0735} \\
\hline & 293 & -6.019 & 11.826 & & \\
\hline & 303 & -6.472 & 13.047 & & \\
\hline & 313 & -8.462 & 25.818 & & \\
\hline & 323 & -9.615 & 35.875 & & \\
\hline \multirow{5}{*}{ CC untreated } & 283 & -3.261 & 3.997 & \multirow{5}{*}{-64.1031} & \multirow{5}{*}{254.0534} \\
\hline & 293 & -4.917 & 7.523 & & \\
\hline & 303 & -5.641 & 9.3813 & & \\
\hline & 313 & -6.235 & 10.976 & & \\
\hline & 323 & -8.133 & 20.654 & & \\
\hline \multirow{5}{*}{ Acid treated } & 283 & -4.893 & 7.999 & \multirow{5}{*}{-72.8767} & \multirow{5}{*}{294.5128} \\
\hline & 293 & -5.335 & 8.933 & & \\
\hline & 303 & -7.283 & 17.998 & & \\
\hline & 313 & -7.995 & 21.582 & & \\
\hline & 323 & -10.02 & 41.745 & & \\
\hline
\end{tabular}<smiles>CN(C)c1ccc(C(c2ccc(C(c3ccc(N(C)C)cc3)c3ccc(N(C)C)cc3)cc2)c2ccc(N(C)C)cc2)cc1</smiles>

Figure 7: Proposed mechanism for CV adsorption on HA and CC.

$$
\Delta G^{\circ}=\Delta H^{\circ}-T \Delta S^{\circ}
$$

A graphical plot was commenced between $\ln K_{\mathrm{D}}$ versus $1 /$ $T$ (Figure 6). Negative values of $\Delta H^{\circ}$ and positive $\Delta S^{\circ}$ [95] show exothermic reaction and increase in arbitrariness of the system [96, 97], as clear from Table 3. Moreover, a spontaneous and favorable adsorption procedure at $283 \mathrm{~K}-323 \mathrm{~K}$ temperatures is shown by negative values of Gibbs energy $\left(\Delta G^{\circ}\right)$ [98]. The magnitude of $K_{d}$ representing distribution coefficient [93] rises with temperature implying that temperature raise increases biosorption. More surface area, expansion of sizes of pores, and activated biosorbent surfaces are responsible for the greater sorption efficiency of the CV dye-modified adsorbents, as compared to raw ones [99-101].

3.8. Mechanism of Adsorption. To understand the adsorption mechanism of the $\mathrm{CV}$ dye, the surface of adsorbent is considered which consists of cellulosic moieties mainly consisting of hydroxyl and carboxyl groups, as seen in the FT-IR analysis. When the adsorbent interacts with acidic groups of tartaric acid, it interacts with the functional groups, thus leading towards increment in acidity of the 
TABLE 4: Comparison of reported adsorbents for CV dye removal.

\begin{tabular}{lcc}
\hline Adsorbents & $Q_{m}(\mathrm{mg} / \mathrm{g})$ & References \\
\hline Coal fly ash zeolites & 19.6 & {$[24]$} \\
Bottom ash zeolites & 17.6 & {$[24]$} \\
Ferula orientalis L. stalks & 125 & {$[23]$} \\
Awka clay & 79.3651 & {$[27]$} \\
Picralima nitida stem & 769.2307 & {$[28]$} \\
Soil clay & 35.71 & {$[30]$} \\
Tartaric acid-modified wheat straw & 112.36 & {$[29]$} \\
Pyrophyllite & 9.58 & {$[32]$} \\
Kola nut pod husk & 1.371 & {$[26]$} \\
H. antidysenterica & 128.2051 & This study \\
H. antidysenterica-tartaric acid modified & 144.9275 & This study \\
C. colocynthis & 136.9863 & This study \\
C. colocynthis-tartaric acid modified & 166.6667 & This study \\
\hline
\end{tabular}

adsorbent which further helps to interact with the adsorption process. The cationic dye in solution dissociates into $\mathrm{CV}^{+}$and $\mathrm{Cl}^{-}$groups that adhere on the surface by interacting with hydrogen bonding with the carboxyl and hydroxyl functionalities (Figure 7). Overall, the adsorption of CV on the adsorbents involves a monolayer procedure including spontaneous occupation of available active surfaces (bulk diffusion) followed by penetration of the adsorbate on the microspores from surface films (pore and intraparticle diffusion steps) and attaining equilibrium stage at the last step (Collins and Elijah, 2019 [102]). Although the Langmuir and pseudo-second-order imply this procedure to be a chemisorption but isotherms such as Temkin and D-R pose it to be a physical one, adsorption of CV dye on raw and modified novel Holarrhena antidysenterica and Citrullus colocynthis is concluded to be a physicochemical one and its maximum adsorption capacity is comparable with reported sorbing materials, as clear from Table 4 .

\section{Conclusion}

Thus, utilization of $H$. antidysenterica and C. colocynthis for effective eradication of $\mathrm{CV}$ dye from wastewaters is considered very effective as it provides the maximum removal efficiencies both in raw and modified forms. Tartaric acid provides the availability of more acidic functional groups such as hydroxyl and carbonyl as seen by FT-IR and SEM analyses. Batch adsorption studies confirmed the modified forms to be better adsorbing than the nonmodified ones. Isothermal studies were performed using Langmuir, Freundlich, Temkin, and D-R models indicating the Langmuir isotherm to be most promising due to highest regression coefficients hence proving monolayer adsorption. $q_{\max }\left(\mathrm{mg} \mathrm{g}^{-1}\right)$ for the HA was $128.2051 \mathrm{mg} \cdot \mathrm{g}^{-1}$ that increased up to $144.9275 \mathrm{mg} \cdot \mathrm{g}^{-1}$ for the tartaric acid forms while CC

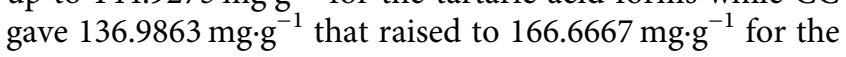
modified ones. Pseudo-second-order kinetics were followed by all the adsorbents. Thermodynamics proved the adsorption procedure to be an exothermic and spontaneous process due to negative values of $\Delta H$ and $\Delta G^{\circ}$. The mechanism involves both bulk and pore diffusion by the adhering dye molecules to the adsorbent via hydrogen bonding and electrostatic interactions. Thus, it is a physicochemical biosorption procedure.

\section{Abbreviations}

FT-IR: Fourier-transform infrared spectroscopy

CV: $\quad$ Crystal violet dye

HA: Holarrhena antidysenterica

CC: $\quad$ Citrullus colocynthis

HA- Holarrhena antidysenterica-tartaric acid modified

TA:

CC-TA: Citrullus colocynthis-tartaric acid modified

SEM: $\quad$ Scanning electron microscopy

PHpzc: Point of zero charge.

\section{Data Availability}

All data related to this work are presented in Results along with references.

\section{Conflicts of Interest}

The authors have no conflicts of interest regarding publication of this paper.

\section{Acknowledgments}

The authors are grateful to the University of the Punjab, Lahore, Pakistan, for funding this project. The authors are thankful to home institute for funding this work.

\section{References}

[1] A. Abourriche, H. Hannache, and M. Oumam, "Elaboration of novel adsorbent from Moroccan oil shale using Plackett-Burman design," Chemistry International, vol. 4, no. 1, pp. 7-14, 2018.

[2] A. M. Abu-Dief and M. M. Zikry, "Adsorption of the heavy metal ions onto bio sorbents: a review," International Journal of Nanomaterials and Chemistry, vol. 4, no. 3, pp. 27-39, 2018.

[3] A. Asghar, A. A. Abdul Raman, and W. M. A. Wan Daud, "Advanced oxidation processes for in-situ production of hydrogen peroxide/hydroxyl radical for textile wastewater treatment: a review," Journal of Cleaner Production, vol. 87, pp. 826-838, 2015.

[4] A. Siddique, A. Hassan, S. R. Khan, A. Inayat, A. Nazir, and M. Iqbal, "Appraisal of heavy metals and nutrients from phosphate rocks," Khyber Pakhtunkhwa, Pakistan, Chemistry International, vol. 4, no. 1, pp. 1-6, 2018.

[5] U. Abbasi, W. Jin, A. Pervez et al., "Anaerobic microbial fuel cell treating combined industrial wastewater: correlation of electricity generation with pollutants," Bioresource Technology, vol. 200, pp. 1-7, 2016.

[6] A. Asadi, A. A. Zinatizadeh, and M. Van Loosdrecht, "A novel continuous feed and intermittent discharge airlift bioreactor (CFIDAB) for enhanced simultaneous removal of carbon and nutrients from soft drink industrial wastewater," Chemical Engineering Journal, vol. 292, pp. 13-27, 2016.

[7] K. Balapure, K. Jain, N. Bhatt, and D. Madamwar, "Exploring bioremediation strategies to enhance the mineralization of textile industrial wastewater through sequential anaerobic- 
microaerophilic process," International Biodeterioration \& Biodegradation, vol. 106, pp. 97-105, 2016.

[8] M. Iqbal, M. Abbas, J. Nisar, A. Nazir, and A. Qamar, "Bioassays based on higher plants as excellent dosimeters for ecotoxicity monitoring: a review," Chemistry International, vol. 5, no. 1, pp. 1-80, 2019.

[9] P. Shao, D. Liang, L. Yang et al., "Evaluating the adsorptivity of organo-functionalized silica nanoparticles towards heavy metals: quantitative comparison and mechanistic insight," Journal of Hazardous Materials, vol. 387, Article ID 121676, 2020.

[10] M. A. Taleb, R. Kumar, A. A. Al-Rashdi, M. K. Seliem, and M. Barakat, "Fabrication of $\mathrm{SiO} 2 / \mathrm{CuFe} 2 \mathrm{O} 4 /$ polyaniline composite: a highly efficient adsorbent for heavy metals removal from aquatic environment," Arabian Journal of Chemistry, vol. 13, no. 10, pp. 7533-7543, 2020.

[11] A. Nezamzadeh-Ejhieh and S. Hushmandrad, "Solar photodecolorization of methylene blue by $\mathrm{CuO} / \mathrm{X}$ zeolite as a heterogeneous catalyst," Applied Catalysis A: General, vol. 388, no. 1-2, pp. 149-159, 2010.

[12] C. R. Marcelo, G. A. Puiatti, M. A. Nascimento, A. F. Oliveira, and R. P. Lopes, "Degradation of the Reactive Blue 4 dye in aqueous solution using zero-valent copper nanoparticles," Journal of Nanomaterials, vol. 2018, Article ID 4642038, 9 pages, 2018.

[13] I. Loulidi, F. Boukhlifi, M. Ouchabi et al., "Adsorption of crystal violet onto an agricultural waste residue: kinetics, isotherm, thermodynamics, and mechanism of adsorption," The Scientific World Journal, vol. 2020, Article ID 5873521, 9 pages, 2020.

[14] M. Bale, "Management of the umbilicus with crystal violet solution," Canadian Medical Association Journal, vol. 124, no. 4, p. 372, 1981.

[15] S. Rashad, A. Zaki, and A. Farghali, "Morphological effect of titanate nanostructures on the photocatalytic degradation of crystal violet," Nanomaterials and Nanotechnology, vol. 9, 2019.

[16] W. Au, M. A. Butler, S. E. Bloom, and T. S. Matney, "Further study of the genetic toxicity of gentian violet," Mutation Research/Genetic Toxicology, vol. 66, no. 2, pp. 103-112, 1979.

[17] J. J. Jones and J. O. Falkinham, "Decolorization of malachite green and crystal violet by waterborne pathogenic mycobacteria," Antimicrobial Agents and Chemotherapy, vol. 47, no. 7, pp. 2323-2326, 2003.

[18] M. Rahmat, A. Rehman, S. Rahmat et al., "Highly efficient removal of crystal violet dye from water by $\mathrm{MnO} 2$ based nanofibrous mesh/photocatalytic process," Journal of $\mathrm{Ma}$ terials Research and Technology, vol. 8, no. 6, pp. 5149-5159, 2019.

[19] M. A. E. Barakat, R. Kumar, M. K. Seliem et al., "Exfoliated clay decorated with magnetic iron nanoparticles for crystal violet adsorption: modeling and physicochemical interpretation," Nanomaterials, vol. 10, no. 8, p. 1454, 2020.

[20] R. Djellabi, M. Fouzi Ghorab, C. L. Bianchi, G. Cerrato, and S. Morandi, "Removal of crystal violet and hexavalent chromium using TiO2-bentonite under sunlight: effect of $\mathrm{TiO} 2$ content," Journal of Chemical Engineering \& Process Technology, vol. 7, no. 1, 2016.

[21] X. Fan, C. Cai, J. Gao, X. Han, and J. Li, "Hydrothermal reduced graphene oxide membranes for dyes removing," Separation and Purification Technology, vol. 241, Article ID 116730, 2020.

[22] E. V. Vidya Vijay, M. Jerold, M. S. Ramya Sankar, S. Lakshmanan, and V. Sivasubramanian,
"Electrocoagulation using commercial grade aluminium electrode for the removal of crystal violet from aqueous solution," Water Science and Technology, vol. 79, no. 4, pp. 597-606, 2019.

[23] T. Aysu and M. M. Küçük, "Removal of crystal violet and methylene blue from aqueous solutions by activated carbon prepared from Ferula orientalis," International Journal of Environmental Science and Technology, vol. 12, no. 7, pp. 2273-2284, 2015.

[24] T. C. R. Bertolini, J. C. Izidoro, C. P. Magdalena, and D. A. Fungaro, "Adsorption of crystal violet dye from aqueous solution onto zeolites from coal fly and bottom ashes," Orbital: The Electronic Journal of Chemistry, vol. 5, no. 3, pp. 179-191, 2013.

[25] S. Chakraborty, S. Chowdhury, and P. D. Saha, "Adsorption of crystal violet from aqueous solution onto sugarcane bagasse: central composite design for optimization of process variables," Journal of Water Reuse and Desalination, vol. 2, no. 1, pp. 55-65, 2012.

[26] N. Chekwube and O. O. Dominic, "Crystal violet adsorption onto Kolanut pod husk activated carbon; isotherm, kinetic, and thermodynamics studies, Sigma," Journal of Engineering \& Natural Sciences/Mühendislik Ve Fen Bilimleri Dergisi, vol. 35, no. 3, 2017.

[27] O. N. Collins and O. C. Elijah, "Adsorption of a dye (crystal violet) on an acid modified non-conventional adsorbent," Journal of Chemical Technology \& Metallurgy, vol. 54, no. 1, 2019.

[28] C. K. Enenebeaku, N. J. Okorocha, U. E. Enenebeaku, and B. I. Onyeachu, "Removal of crystal violet dye by adsorption onto picrilima nitida stem bark powder: kinetics and isotherm studies," IOSR Journal of Applied Chemistry, vol. 9, pp. 14-23, 2016.

[29] R. Gong, Y. Liu, Y. Jiang, and C. Li, "Isothermal, kinetic and thermodynamic studies on basic dye sorption onto tartaric acid esterified wheat straw," African Journal of Biotechnology, vol. 8, no. 24, pp. 7138-7147, 2009.

[30] A. Ibrahim, G. F. El Fawal, and M. A. Akl, "Methylene blue and crystal violet dyes removal (as A binary system) from aqueous solution using local soil clay: kinetics study and equilibrium isotherms," Egyptian Journal of Chemistry, vol. 62, no. 3, pp. 541-554, 2019.

[31] A. Mittal, J. Mittal, A. Malviya, D. Kaur, and V. K. Gupta, "Adsorption of hazardous dye crystal violet from wastewater by waste materials," Journal of Colloid and Interface Science, vol. 343, no. 2, pp. 463-473, 2010 b.

[32] Y. Miyah, A. Lahrichi, M. Idrissi, S. Boujraf, H. Taouda, and F. Zerrouq, "Assessment of adsorption kinetics for removal potential of Crystal Violet dye from aqueous solutions using Moroccan pyrophyllite," Journal of the Association of Arab Universities for Basic and Applied Sciences, vol. 23, no. 1, pp. 20-28, 2017.

[33] H. Parab, M. Sudersanan, N. Shenoy, T. Pathare, and B. Vaze, "Use of agro-industrial wastes for removal of basic dyes from aqueous solutions," CLEAN - Soil, Air, Water, vol. 37, no. 12, pp. 963-969, 2009.

[34] M. A. Rauf, S. B. Bukallah, F. A. Hamour, and A. S. Nasir, "Adsorption of dyes from aqueous solutions onto sand and their kinetic behavior," Chemical Engineering Journal, vol. 137, no. 2, pp. 238-243, 2008.

[35] B. S. Kaith, J. Dhiman, and J. Kaur Bhatia, "Preparation and application of grafted Holarrhena antidycentrica fiber as cation exchanger for adsorption of dye from aqueous 
solution," Journal of Environmental Chemical Engineering, vol. 3, no. 2, pp. 1038-1046, 2015.

[36] S. Sinha, A. Sharma, P. H. Reddy, B. Rathi, N. V. S. R. K. Prasad, and A. Vashishtha, "Evaluation of phytochemical and pharmacological aspects of Holarrhena antidysenterica (Wall.): a comprehensive review," Journal of Pharmacy Research, vol. 6, no. 4, pp. 488-492, 2013.

[37] M. R. R. Kahkha, M. Kaykhaii, and G. Ebrahimzadeh, "Optimization of affective parameter on cadmium removal from an aqueous solution by Citrullus colocynthis powdered fruits by response surface," Health Scope, vol. 4, no. 1, 2015.

[38] A. E. Al-Snafi, "Chemical constituents and pharmacological effects of Citrullus colocynthis-A review," IOSR Journal of Pharmacy, vol. 6, no. 3, pp. 57-67, 2016.

[39] Y. Chen, Y. Zhu, Z. Wang et al., "Application studies of activated carbon derived from rice husks produced by chemical-thermal process-A review," Advances in Colloid and Interface Science, vol. 163, no. 1, pp. 39-52, 2011.

[40] S. S. Pillai, M. D. Mullassery, N. B. Fernandez, N. Girija, P. Geetha, and M. Koshy, "Biosorption of $\mathrm{Cr}(\mathrm{VI})$ from aqueous solution by chemically modified potato starch: equilibrium and kinetic studies," Ecotoxicology and Environmental Safety, vol. 92, pp. 199-205, 2013.

[41] A. Yargıç, R. Y. Şahin, N. Özbay, and E. Önal, “Assessment of toxic copper (II) biosorption from aqueous solution by chemically-treated tomato waste," Journal of Cleaner Production, vol. 88, pp. 152-159, 2015.

[42] L. W. Low, T. T. Teng, N. Morad, and B. Azahari, "Studies on the adsorption of methylene blue dye from aqueous solution onto low-cost tartaric acid treated bagasse," APCBEE Procedia, vol. 1, pp. 103-109, 2012.

[43] B. C. S. Ferreira, F. S. Teodoro, A. B. Mageste, L. F. Gil, R. P. de Freitas, and L. V. A. Gurgel, "Application of a new carboxylate-functionalized sugarcane bagasse for adsorptive removal of crystal violet from aqueous solution: kinetic, equilibrium and thermodynamic studies," Industrial Crops and Products, vol. 65, pp. 521-534, 2015.

[44] T. Mahmud, "Biosorption of Auramine O and Drimarene dyes from aqueous solutions using seed powder of Diospyros lotus," International Journal of Environment and Sustainability, vol. 6, no. 3, 2018.

[45] U. Farooq, M. A. Khan, M. Athar, M. Sakina, and M. Ahmad, "Environmentally benign urea-modifed Triticum aestivum biomass for lead (II) elimination from aqueous solutions," CLEAN-Soil, Air, Water, vol. 38, no. 1, pp. 49-56, 2010.

[46] V. O. S. Neto, T. V. Carvalho, S. B. Honorato et al., "Coconut bagasse treated by thiourea/amonium solution for cadmium removal: kinetic and adsorption equilibrium," BioResources, vol. 7, no. 2, pp. 1504-1524, 2012.

[47] J. Mao, S. W. Won, K. Vijayaraghavan, and Y.-S. Yun, "Immobilized citric acid-treated bacterial biosorbents for the removal of cationic pollutants," Chemical Engineering Journal, vol. 162, no. 2, pp. 662-668, 2010.

[48] W. E. Marshall, L. H. Wartelle, D. E. Boler, M. M. Johns, and C. A. Toles, "Enhanced metal adsorption by soybean hulls modified with citric acid," Bioresource Technology, vol. 69, no. 3, pp. 263-268, 1999.

[49] K. K. Wong, C. K. Lee, K. S. Low, and M. J. Haron, "Removal of $\mathrm{Cu}$ and $\mathrm{Pb}$ by tartaric acid modified rice husk from aqueous solutions," Chemosphere, vol. 50, no. 1, pp. 23-28, 2003.

[50] K. S. Low, C. K. Lee, S. Y. Wong, and P. L. Tang, "Metal soprtion enhancement of rice hull through chemical modification," Environmental Technology, vol. 21, no. 11, pp. 1239-1244, 2000.

[51] R. Rehman, T. Mahmud, and J. Anwar, "Isothermal modeling of batch biosorption of brilliant green dye from water by chemically modified eugenia," Journal Chemical Society Pakistan, vol. 34, no. 1, pp. 136-143, 2012.

[52] N. Almoisheer, F. A. Alseroury, R. Kumar, T. Almeelbi, and M. A. Barakat, "Synthesis of graphene oxide/silica/carbon nanotubes composite for removal of dyes from wastewater," Earth Systems and Environment, vol. 3, no. 3, pp. 651-659, 2019.

[53] M. Zazouli, D. Balarak, Y. Mahdavi, and M. Ebrahimi, "Adsorption rate of 198 reactive red dye from aqueous solutions by using activated red mud," Iranian Journal of Health Sciences, vol. 1, no. 1, pp. 36-43, 2013.

[54] M. K. Seliem, M. Barczak, I. Anastopoulos, and D. A. Giannakoudakis, "A novel nanocomposite of activated serpentine mineral decorated with magnetic nanoparticles for rapid and effective adsorption of hazardous cationic dyes: kinetics and equilibrium studies," Nanomaterials, vol. 10, no. 4, p. 684, 2020.

[55] V. V. Khadake and S. Deshmukh, "Kinetic parameters and evaluation performance for decolorization using low cost adsorbent," International Proceedings of Chemical, Biological and Environmental Engineering (IPCBEE), vol. 28, pp. 95-99, 2012.

[56] M. Naushad, G. Sharma, A. Kumar et al., "Efficient removal of toxic phosphate anions from aqueous environment using pectin based quaternary amino anion exchanger," International Journal of Biological Macromolecules, vol. 106, pp. 110, 2018.

[57] H. Ding, X. Luo, X. Zhang, and H. Yang, "Alginateimmobilized Aspergillus Niger: characterization and biosorption removal of thorium ions from radioactive wastewater," Colloids and Surfaces A: Physicochemical and Engineering Aspects, vol. 562, pp. 186-195, 2019.

[58] N. K. Gupta, A. Gupta, P. Ramteke, H. Sahoo, and A. Sengupta, "Biosorption-a green method for the preconcentration of rare earth elements (REEs) from waste solutions: a review," Journal of Molecular Liquids, vol. 274, pp. 148-164, 2019.

[59] M. R. Hadiani, K. Khosravi-Darani, and N. Rahimifard, "Optimization of as (III) and as (V) removal by Saccharomyces cerevisiae biomass for biosorption of critical levels in the food and water resources," Journal of Environmental Chemical Engineering, vol. 7, no. 2, Article ID 102949, 2019.

[60] A. Chham, E. Khouya, M. Oumam et al., "The use of insoluble mater of Moroccan oil shale for removal of dyes from aqueous solution," Chemistry International, vol. 4, no. 1, pp. 67-77, 2018.

[61] A. Gouza, K. Fanidi, S. Saoiabi, A. Laghzizil, and A. Saoiabi, "Effect of heat treatment on the surface properties of selected bituminous shale for cationic dye sorption," Desalination and Water Treatment, vol. 66, pp. 274-280, 2017.

[62] M. El Haddad, R. Slimani, R. Mamouni, S. ElAntri, and S. Lazar, "Removal of two textile dyes from aqueous solutions onto calcined bones," Journal of the Association of Arab Universities for Basic and Applied Sciences, vol. 14, no. 1, pp. 51-59, 2013.

[63] M. A. Barakat, R. Kumar, M. Balkhyour, and M. A. Taleb, "Novel Al2O3/GO/halloysite nanotube composite for sequestration of anionic and cationic dyes," RSC Advances, vol. 9, no. 24, pp. 13916-13926, 2019. 
[64] M. B. Ibrahim, M. A. Haruna, and A. M. Ibrahim, "Optimization of Crystal Violet dye removal from aqueous solution using agro wastes," ChemSearch Journal, vol. 3, no. 1, pp. 28-33, 2012.

[65] R. Rehman, A. Abbas, A. Ayub, M. Salman, T. Mahmud, and U. Shafique, "Comparative study of Brilliant Green dye adsorption from water by radish peels, Jamun stem and coal," Electronic Journal of Environmental, Agricultural \& Food Chemistry, vol. 10, no. 7, 2011.

[66] J. O. Eniola, R. Kumar, A. A. Al-Rashdi, M. O. Ansari, and M. A. Barakat, "Fabrication of novel $\mathrm{Al}(\mathrm{OH}) 3 / \mathrm{CuMnAl}$ layered double hydroxide for detoxification of organic contaminants from aqueous solution," ACS Omega, vol. 4, no. 19, pp. 18268-18278, 2019.

[67] I. Langmuir, "The adsorption of gases on plane surfaces of glass, mica and platinum," Journal of the American Chemical Society, vol. 40, no. 9, pp. 1361-1403, 1918.

[68] H. Freundlich, "Over the adsorption in solution," Journal of Physical Chemistry, vol. 57, no. 385471, pp. 1100-1107, 1906.

[69] A. Mittal, J. Mittal, A. Malviya, and V. K. Gupta, "Removal and recovery of Chrysoidine $\mathrm{Y}$ from aqueous solutions by waste materials," Journal of Colloid and Interface Science, vol. 344 , no. 2 , pp. 497-507, 2010a.

[70] D. Ringot, B. Lerzy, K. Chaplain, J.-P. Bonhoure, E. Auclair, and Y. Larondelle, "In vitro biosorption of ochratoxin A on the yeast industry by-products: comparison of isotherm models," Bioresource Technology, vol. 98, no. 9, pp. 1812-1821, 2007.

[71] M. Samarghandi, M. Hadi, S. Moayedi, and A. F. Barjesteh, "Two-parameter isotherms of methyl orange sorption by pinecone derived activated carbon," Iranian Journal of Environmental Health Science \& Engineering, vol. 6, no. 4, pp. 285-294, 2009.

[72] M. H. Jnr and A. I. Spiff, "Equilibrium sorption study of $\mathrm{Al} 3+, \mathrm{Co} 2+$ and $\mathrm{Ag}+$ in aqueous solutions by fluted pumpkin (Telfairia occidentalis HOOK f) waste biomass," Acta Chimica Slovenica, vol. 52, pp. 174-181, 2005.

[73] C. Theivarasu and S. Mylsamy, "Equilibrium and kinetic adsorption studies of Rhodamine-B from aqueous solutions using cocoa (Theobroma cacao) shell as a new adsorbent," International Journal of Engineering Science Technology, vol. 2, no. 11, pp. 6284-6292, 2010.

[74] C. C. Travis and E. L. Etnier, "A survey of sorption relationships for reactive solutes in soil," Journal of Environmental Quality, vol. 10, no. 1, pp. 8-17, 1981.

[75] U. Israel and U. Eduok, "Biosorption of zinc from aqueous solution using coconut (Cocos nucifera L) coir dust," Archives of Applied Science Research, vol. 4, no. 2, pp. 809-819, 2012.

[76] R. Abdul, M. Tariq, A. Muhammad, R. Rabia, and B. Sumaira, "Usage of fruit-fibers of Luffa cylindrica for the sorptive removal of Direct Blue 15 dye from water," Desalination and Water Treatment, vol. 120, pp. 350-360, 2018.

[77] S. M. Al-Garni, "Biosorption of lead by Gram-ve capsulated and non-capsulated bacteria," Water S. A, vol. 31, no. 3, pp. 345-350, 2005.

[78] M. Gubernak, W. Zapala, and K. Kaczmarski, "Analysis of amylbenzene adsorption equilibria on an RP-18e chromatographic column," Acta Chromatographica, vol. 13, 2003.

[79] O. Hamdaoui and E. Naffrechoux, "Modeling of adsorption isotherms of phenol and chlorophenols onto granular activated carbon: Part I. Two-parameter models and equations allowing determination of thermodynamic parameters,"
Journal of Hazardous Materials, vol. 147, no. 1-2, pp. 381394, 2007.

[80] A. Achmad, J. Kassim, T. K. Suan, R. C. Amat, and T. L. Seey, "Equilibrium, kinetic and thermodynamic studies on the adsorption of direct dye onto a novel green adsorbent developed from Uncaria gambir extract," Journal of Physical Science, vol. 23, no. 1, pp. 1-13, 2012.

[81] S. K. Lagergren, "About the theory of so-called adsorption of soluble substances," Sven. Vetenskapsakad. Handingarl, vol. 24, pp. 1-39, 1898.

[82] W. Zhu, J. Liu, and M. Li, "Fundamental studies of novel zwitterionic hybrid membranes: kinetic model and mechanism insights into strontium removal," The Scientific World Journal, vol. 2014, Article ID 485820, 7 pages, 2014.

[83] Y. S. Ho and G. McKay, "Sorption of dye from aqueous solution by peat," Chemical Engineering Journal, vol. 70, no. 2, pp. 115-124, 1998.

[84] K. D. Kowanga, E. Gatebe, G. O. Mauti, and E. M. Mauti, "Kinetic, sorption isotherms, pseudo-first-order model and pseudo-second-order model studies of $\mathrm{Cu}$ (II) and $\mathrm{Pb}$ (II) using defatted Moringa oleifera seed powder," Journal of Phytopharmacy, vol. 5, no. 2, pp. 71-78, 2016.

[85] S. Chawla, H. Uppal, M. Yadav, N. Bahadur, and N. Singh, "Zinc peroxide nanomaterial as an adsorbent for removal of Congo red dye from waste water," Ecotoxicology and Environmental Safety, vol. 135, pp. 68-74, 2017.

[86] V. Verma and A. Mishra, "Kinetic and isotherm modeling of adsorption of dyes onto rice husk carbon," Global NEST Journal, vol. 12, no. 2, pp. 190-196, 2010.

[87] C. Tang, Y. Zhang, J. Han, Z. Tian, L. Chen, and J. Chen, "Monitoring graphene oxide's efficiency for removing $\operatorname{Re}(\mathrm{VII})$ and $\mathrm{Cr}(\mathrm{VI})$ with fluorescent silica hydrogels," Environmental Pollution, vol. 262, Article ID 114246, 2020.

[88] V. Ponnusami, V. Gunasekar, and S. Srivastava, "Kinetics of methylene blue removal from aqueous solution using gulmohar (Delonix regia) plant leaf powder: multivariate regression analysis," Journal of Hazardous Materials, vol. 169, no. 1-3, pp. 119-127, 2009.

[89] H. K. Boparai, M. Joseph, and D. M. O’Carroll, "Kinetics and thermodynamics of cadmium ion removal by adsorption onto nano zerovalent iron particles," Journal of Hazardous Materials, vol. 186, no. 1, pp. 458-465, 2011.

[90] Q. Zhu, G. D. Moggridge, and C. D'Agostino, "Adsorption of pyridine from aqueous solutions by polymeric adsorbents MN 200 and MN 500. Part 2: kinetics and diffusion analysis," Chemical Engineering Journal, vol. 306, pp. 1223-1233, 2016.

[91] A. Benmessaoud, D. Nibou, E. H. Mekatel, and S. Amokrane, "A comparative study of the linear and non-linear methods for determination of the optimum equilibrium isotherm for adsorption of $\mathrm{Pb} 2+$ ions onto Algerian treated clay," Iranian Journal Chemistry and Chemical Engineering, vol. 39, no. 4, 2020.

[92] N. Benderdouche, B. Bestani, and M. Hamzaoui, "The use of linear and nonlinear methods for adsorption isotherm optimization of basic green 4-dye onto sawdust-based activated carbon," Journal of Material Environmental Science, vol. 9, pp. 1110-1118, 2018.

[93] C. A. Igwegbe, O. D. Onukwuli, K. K. Onyechi, and S. Ahmadi, "Equilibrium and kinetics analysis on vat yellow 4 uptake from aqueous environment by modified rubber seed shells: nonlinear modelling," Journal Materials Environmental Science, vol. 11, no. 9, pp. 1424-1444, 2020.

[94] M. Naushad, "Surfactant assisted nano-composite cation exchanger: development, characterization and applications 
for the removal of toxic $\mathrm{Pb} 2+$ from aqueous medium," Chemical Engineering Journal, vol. 235, pp. 100-108, 2014.

[95] C. Igwegbe, P. Onyechi, and O. Onukwuli, "Kinetic, isotherm and thermodynamic modelling on the adsorptive removal of malachite green on Dacryodes edulis seeds," Journal of Scientific and Engineering Research (An International Journal), vol. 2, pp. 23-39, 2015.

[96] M. Naushad, T. Ahamad, G. Sharma et al., "Synthesis and characterization of a new starch/SnO2 nanocomposite for efficient adsorption of toxic $\mathrm{Hg} 2+$ metal ion," Chemical Engineering Journal, vol. 300, pp. 306-316, 2016.

[97] J. Thilagan, S. Gopalakrishnan, and T. Kannadasan, "Thermodynamic study on adsorption of Copper (II) ions in aqueous solution by Chitosan blended with Cellulose \& cross linked by Formaldehyde, Chitosan immobilised on Red Soil, Chitosan reinforced by Banana stem fibre," International Journal of Scientific Research Engineering \& Technology, vol. 2, no. 1, 2013.

[98] J. O. Ighalo and A. G. Adeniyi, "Adsorption of pollutants by plant bark derived adsorbents: an empirical review," Journal of Water Process Engineering, vol. 35, Article ID 101228, 2020.

[99] G. Chaya, Studies on Removal of Toxic Dyes and Heavy Metals from Contaminated Water Using Low Cost Biosorbents, 2018, https://shodhganga.inflibnet.ac.in/handle/10603/251022URI: \%20http://hdl.handle.net/10603/251022.

[100] I. Gaballah and G. Kilbertus, "Recovery of heavy metal ions through decontamination of synthetic solutions and industrial effluents using modified barks," Journal of Geochemical Exploration, vol. 62, no. 1-3, pp. 241-286, 1998.

[101] M. Shanthi and V. Kuzhalosai, "Photocatalytic degradation of an azo dye, Acid Red 27, in aqueous solution using nano $\mathrm{ZnO}$," Indian Journal of Chemistry, vol. 51A, pp. 428-434, 2012.

[102] M. Mohammad, S. Maitra, N. Ahmad, A. Bustam, T. Sen, and B. K. Dutta, "Metal ion removal from aqueous solution using physic seed hull," Journal of Hazardous Materials, vol. 179, no. 1-3, pp. 363-372, 2010. 